\title{
Karolenj Rönesansı Bağlamında Kütüphaneler, Manastırlar ve Karolenj El Yazmaları
}

\section{Libraries, Monasteries and Carolingian Manuscripts in the Context of the Carolingian Renaissance}

\section{Seda Demir*}

$\ddot{\boldsymbol{O}} \boldsymbol{z}$

774 yllında tahta geçen Kral Şarlman, ruhban sınıfinın manevi çöküntü içinde olduğunu düşünüyordu. Kralın adıyla anılan Karolenj Rönesansı'nın en önemli girişimlerinden biri ruhban sınıfinı bilge keşişlere dönüştürmek, prensleri ise donanımlı devlet adamları olarak yetişstirebilecek entelektüel eğitimi sağlamaktı. Amaç: Bu bilgilerden hareketle çalışma, 16. yüzyılda Avrupa'yı etkisi altına alan büyük İtalyan Rönesansı'ndan önce ortaya çıkarak muhtemelen bu rönesansın öncülü sayllabilecek bir dönem olan Karolenj döneminin entelektüel boyutu içinde manastır kütüphanelerini ele almayı amaçlamaktadır. Çalışma ayrıca Kral Şarlman zamanı entelektüel anlayışının Kilise ile olan bağlantısını ortaya koymaya, aynı zamanda Klasik dönem el yazmalarının Karolenj manastır ve saray kütüphanelerinde çoğaltılmasının ve bu el yazmalarının Karolenj Rönesansı açısından öneminin altını çizmeye çalışmaktadır. Yöntem: Çalışmada kronolojik sıralama yöntemi ile Kilise-devlet ilişkileri entelektüel gelişim ve kütüphanelerdeki kitap çoğaltıma etkinliği açısından önemli noktalarla ele alınmıştır. Bulgular: Çalışmada, elde edilen bulgulara göre Kral Şarlman'ın, Kutsal Roma Imparatoru unvanını alması ile Kilise-devlet ilişkisi imparatorlukta oldukça bütünleşmiştir. Bu durumun manastırlar ve kütüphaneleri üzerindeki en önemli etkilerinden biri ise katedrallerin yanı sıra dini eğitimin merkezi olarak görülen manastırların bünyesinde yazmanlık faaliyetlerindeki dinamizmdir. Bu dönemde manastır yazlhanelerinde Klasik Dönem eserlerinin çoğaltılma hızlarında, değerlerinde ve fiziksel niteliklerine ilişkin algılarda bazı değişimler söz konusudur. Sonuç: Kilise-devlet ilişkisinin dini ve entelektüel etkileri söz konusudur. Kilise ile olan ilişkilerin, manastırlar bünyesinde kitap çoğaltılmasını hızlandırma ve zenginleştirme açısından doğrudan etkili olduğu ve Karolenj dönemiyle birlikte zaman içinde ortaya çıkan el yazması ekollerinde değişiklik görüldüğ̈̈ sonucuna ulaşılmıştır. Özgünlük: Ulusal literatür içerisinde Karolenj Rönesansı ve entelektüel alana nüfuzu ile ilgilenen oldukça sınırlı sayıda çalışma mevcutken, konunun manastır ve katedral gibi dini kurumlar bünyesindeki kütüphaneleri odaklanmış türden herhangi bir çalışmaya ise rastlanmamıştır.

Anahtar Sözcükler: Charlemagne; Karolenj el yazmalarl; Karolenj Minüskülü; Karolenj Rönesansı; kitap çoğaltma.

\footnotetext{
* Sakarya Üniversitesi, Türkçe Eğitimi, Sakarya, Türkiye. E-posta: serkoc_16@hotmail.com Sakarya University, Turkish Education Department.E-mail: serkoc_16@hotmail.com
}

Geliş Tarihi - Received: 13.11 .2020

Kabul Tarihi - Accepted: 08.06.2021

Yayımlanma Tarihi - Published: 30.06.2021 
Abstract

King Charlemagne, who came to the throne in 774, thought that the clergy were in a spiritual collapse. One of the most important initiatives of the Carolingian Renaissance named after the King himself, was to transform the clergy into wise monks and to provide the intellectual education that could train the princes to be well-equipped statesmen. Objective: Based on this information, the study aims to deal with the monastic libraries within the intellectual dimension of the Carolingian period, a period that emerged before the great Italian Renaissance, which took over Europe in the 16th century, and can probably be considered the precursor of this renaissance as well. The study also tries to reveal the connection of the intellectual understanding of King Charlemagne's time with the Church, while at the same time trying to underline the importance of the reproduction of Classical period manuscripts in Carolingian monastic and palace libraries besides the importance of these manuscripts for the Carolingian Renaissance. Method: In the study, church-state relations are discussed with important points in terms of intellectual development and the efficiency of book reproduction in libraries with the method of depicting according to chronological order. Findings: In the study, according to the findings obtained, the Church-state relationship became more highly integrated in the empire with King Charlemagne's taking the title of Holy Roman Emperor. One of the most important effects of this situation in monasteries and libraries is the dynamism seen in the manuscript writing activities within the monasteries, which are considered as the center of religious education along with the cathedrals. During this period, there were some changes in the reproduction rate, values, and perceptions of the physical qualities of the Classical works in scriptoriums. Implications: The Church-state relations have some religious and intellectual implications. It has been concluded that the relations with the church directly affected the reproduction of books in monasteries in the direction of accelerating and enriching, and that there was a change in the manuscript schools that emerged over time with the Carolingian period. Originality: While there is a very limited number of studies dealing with the Carolingian Renaissance and its influence on the intellectual field in the national literature, but no study has been found concerning the libraries of religious institutions such as monasteries and cathedrals.

Keywords: Charlemagne; Carolingian illuminated manuscripts; Carolingian Minuscule; Carolingian Renaissance; Manuscript production.

\section{Giriș}

Karolenj Rönesansı, Batı literatüründe oldukça uzun süredir kapsamlı bir çalışma alanı oluşturmaktadır ve hakkında çeşitli açılardan yüzlerce çalışma yapılmış tarihsel bir olgudur. Bu dönemin entelektüel olduğu kadar sosyal, dini ve siyasi açıları da vardır. Çalışma, Türkiye'deki ilgili literatür birikimine manastır ve manastır kütüphanelerinde kitap çoğaltılması açısından Karolenj döneminin entelektüel yönüne ilişkin katkı sağlamak amacıyla gerçekleştirilmiştir. Türkiye'de konu ile ilgili yapılan çalışmalar neredeyse yok denecek kadar azken, söz konusu döneme ilişkin ortaya konulan akademik çalışmaların çoğu Frank imparatorluğunun daha çok askeri, dini ve siyasi boyutuna yoğunlaşmıştır. Bu noktada çalışmanın Karolenj dönemi manastır kütüphaneleri ve yazıhanelerine ilişkin bilgiler içeren nadir çalışmalardan biri olduğu ifade edilebilir. 
Karolenj Rönesansı'nı gerçekleştiren Şarlman'ın üyesi olduğu Karolenj hanedanlığı günümüzde Frank olarak adlandırdığımız Doğu Fransa, Batı Almanya ve bu iki coğrafyanın aşağ1 kısımlarında kalan "Austrasia" olarak bilinen bölgede hakimdi. Onun ataları kendilerinden önce gelen Merovenj hanedanı ile herhangi bir kan bağı bulunmayan hükümdarların ve kraliyetin sözde hizmetkarlarıydı. İlgili kaynaklarda (Cairns, 2009, s. 178; Frassetto, 2013, s. 90; Riché, 1993, s. 50) söz konusu hanedan üyelerinin görevine işaret etmek için kullanılan "mayor in palace" tercümesi ile "sarayın belediye başkanı" tabiri, bir yönden oldukça dikkat çekicidir. Latincesi mayor domus veya mayor palati'dir. Özellikle Merovenj hanedanlığı zamanında, kralın kişiliğinden ayrı kabul edilen, siyasi ve idari ihtiyaçlara cevap veren gerçek erkin altyapısını desteklemek için tek taraflı bir iktidar pozisyonunu değil, 'bir görevlinin desteğine bağlı olduğu güçlüler konseyi' fikrini desteklemek için ortaya çıkmış bir görev tanımıdır. Kral ve bu devlet görevlileri, belirli şekillerde ülkeyi birlikte yönetmişlerdir (Schutz, 2004, s. 19). Karolenj hanedanlarının saraydaki görevlerinin tam karşılığından söz etmek gerekirse, söz konusu unvanın genellikle "saray sorumlusu" veya "sarayın belediye başkanı" şeklinde tercüme edilebileceği söylenebilir. Ancak bu tercümenin günümüz algısı ve tabiri ile belediye başkanı unvanını değil; bir tür başbakan ya da askeri lideri -başbakan ve savunma bakanını- işaret ettiğini belirtmek gerekir. Şarlman, kendi hanedanlığından önce gelen ve "sarayın belediye başkanı" olarak görülen Merovenj hanedanlığını yönetimde etkisiz hale getiren Karolenj hanedanlığındandır. 5. yüzyılda Batı Roma İmparatorluğu'nun yıkılmasından sonra Avrupa'yı işgal ve talana başlayan kavimlerin entelektüel anlamda kendini geliştiren en ünlü hükümdarıdır.

\section{Yöntem}

Çalışmada önce Karolenj Rönesansı ve Şarlman'ın entelektüel ve litürji ${ }^{1}$ alanlarında yaptığı reformların Kilise-devlet ilişkisi açısından gelişimine kronolojik sıralama yöntemi ile yer verilmiştir. Sonrasında Karolenj döneminde manastırlarda yoğun olarak üretilen el yazmalarının türleri ve niteliklerini belirleyen etmenlere ilişkin saptamalarda bulunulmuştur. Önceki dönem el yazmalarının farklılıklarına açıklık getirmek için karakteristik özellikleri ve örnekleri ile birlikte Karolenj döneminin önde gelen el yazmalarına yer verilmiştir. Sonuç kısmında ise entelektüel gelişim ve kütüphanelerdeki kitap çoğaltma etkinliği önemli noktalarla ele alınarak saptamalarda bulunulmuştur.

\section{Şarlman'ın Kilise ile İlişkileri}

Şarlman için Kilise, devletin en önemli kurumuydu. Roma ile irtibat halinde olmak ve Papalarla yapılan görüşmeler, Şarlman'ın büyük hedeflerinden biri olan Kutsal Roma Germen İmparatorluğu'nu kurulabilmesi için gerekliydi. Bunu başarmanın yolları da Papa Hadrian'ın Roma'sını Lombard kralına karşı korumak, daha sonraları ise sonraki Papa III. Leo'nun azledildiği Papalık'a yeniden erişebilmesinde yardımcı olmaktan geçiyordu. Şarlman İspanya'da savaştı. Avarları, dönemin saldırgan ve yağmacı bir kavmi olan Saksonlar'ı yendi. Tüm bu zaferler onu Papalarla kurduğu ilişkiler nazarında dini merkez olan Roma'nın askeri ve siyasi hamisi statüsüne yükseltiyor gibiydi (Hodgkin, 1902).

\footnotetext{
${ }^{1}$ Hristiyanlıkta toplu ve cemaatle yani halka açık olarak yapılan ibadet, ayin ve törenlerin yapılış şekillerine yönelik yazılı ve uygulamalı bilgiler bütünü.
} 
Şarlman'a göre iyi bir devlet yöneticisi dindar niteliklere sahip olmalıydı. Yönetime geçtiği andan itibaren sergilediği yönetim ve davranışların merkezine oturttuğu Kiliseye yönelik siyasi etkinlikler hep Kilise ile imparatorluğun arasını sıcak ve ilişkileri sağlam tutma yönündeydi. Bu şekilde bir ilişki ile Roma'ya bağlı olan Şarlman, bu ilişkiyi siyasi erki için kaçınılmaz buluyordu. Kilise'nin sözünden çıkmayacak şekilde, Papa ile tam bir uyum içinde siyaset izlediğini söylemek ise güçtü. Kral, yeri geldiğinde din adamlarını çeşitli konularda sorgulamış, Kilise'nin sergilediği tutum veya eylemlerinden dolayı onların bu gücüne karşı durmaktan kaçınmamıştır. Düzenli sayılabilecek farklı amaçlı ziyaretler, hediyeleşmeler, gerektiğinde Papa'yı koruma gibi nedenlerle neredeyse Roma'yı etkisi altında tutmaya yakın tavırlar sergilemiştir. Halkın Papalıktan azlettiği III. Leo’yu hasımlarına karşı koruyarak şehre getirip makamına tekrar geçmesini sağlamıştır. Kendisinin ve piskoposlarının davetli olmadığ 1 için katılamadığı 787 yılındaki II. İznik Konsili’nde alınan kararları hatalı tercüme sonucu yanlış anlamış ve sonrasında kabul etmiştir. Ancak öncesinde reddedip Libri Carolini isimli eseri yazdırıp Papa'ya gönderecek kadar kararlı bir tutum sergilemiştir (Genç, 2013). Bu Konsilin en önemli noktası Ikonoklazm'dır. "Ikonoklazm, resim ve put kırmak anlamındadır" (Aydın, 2005, s. 329). Ayrıca dini veya kültürel değer taşıyan her türlü somut ögenin başka dini, siyasi veya kültürel sebeplerle kasten yok edilmesidir de denilebilir. Tarihte, ilk akla gelen örneği, iki dönem olarak yaşanan Bizans ikonoklazmıdır. 787'de İkinci İznik Konsili'nde ikonoklazmı lanetlemesiyle ve burada alınan kararlarla ilgili olarak Şarlman'ın verdiği tepki, kitap yazdırmaya kadar ilerlediği için oldukça belirgindir. "Öyle ki, "Papa Hadrian, Şarlman'a İznik Konsili'nin bir tercümesini iletmiş, kendisi burada görüşülenleri kabul etmiş ve İmparator'un da aynısını yapmasını beklemiştir. Konsil, Almanya ve Fransa'nın din adamları arasında İtalya'dan aldığ 1 tepkilerden çok farklı bir tepkiyle karşılaşmıştır. Çünkü Kral bu metni kendi din adamlarının ellerine vermiştir. Din adamları onun adına, "Libri Carolini” adıyla anılan dört kitabı, bu Konsil'in içinde buldukları doktrin ve hatalara bir itiraz olarak yayınlamıştır. Eser, yüz yirmi bölümden oluşmaktadır ve bu bölüm, gerçek ya da varsayılan bazı hataların sansüre tabi tutulmasıyla oluşturulmuştur" (Painter, 1850, s. LXXIX). İmparatorun Hristiyanlığın merkezi ile siyasi ve askeri açılardan bağlantılı olması, Kilisenin bir reform veya rönesans niteliğinde düzenlemeye hedef seçilmesinde Papa ile müttefiklik açısından oldukça anlamlıdır.

Kral, Kilise ile olan ilişkileri konusunda oldukça ciddi davranmıştır. Öyle ki bu amaçla oğlunun Papa tarafından yeniden isimlendirilmesini istemiştir. Bir kral namzeti veya asil bir çocuğun dinen onaylanması yani kiliseye resmen kabul edilmesini -ve hatta vaftizinigeciktirmenin Karolenj emsalleri zaten Şarlman'dan önce de görülmüştür. Bunun amacı ileride faydası dokunacak yararlı bir dostluk, ruhani birlik veya ilişki yaratmak veya müttefik kazanmaktır. Şarlman ve Papa Hadrian, ruhsal yakınlık olarak adlandırılan "compater spiritalis" isimli ilişkilerini oluşturduğunda, genç Carloman- daha sonra Papa'nın ona vereceği isim ile Pepin-, yedi yaşına kadar vaftiz edilmemiştir. Hadrian ve Şarlman arasındaki sonraki yazışmalarda Carloman/Pepin'den nadiren bahsedilse de bu ritüel ile yetişkinlerin ilişkilerinin altı tekrar çizilmiştir. Zaten Papa Hadrian ve Şarlman mektuplarında her zaman birbirlerine compater spiritalis şeklinde hitap etmiştir (Lynch ve Lynch, 1998, s. 120). Özetle, her ikisi arasında ruhani boyutu da etkileyecek kadar derin bir ilişki olduğu bilinmektedir. 
Şarlman, Kilise'de çeşitli şekillerde reformlar yapmaya başlamıştır. 789 tarihli Admonitio Generalis ismiyle çıkardığ 1 kanunda, rahiplerin, kutsal kitapta emredildiği gibi, adaletli ve uygun bir yaşam sürmelerini, böylece insanların Tanrı'nın hizmetine yönlendirilmesini talep etmiştir (Butt, 2002, s. 110). Bu kanun, hükümdarının eğitimsel ve dini hedeflerini ve ideallerini ilan ederek Karolenj Rönesansı'nın temelini oluşturan Kiliseye yönelik yasa metnidir. Admonitio Generalis (Genel Admonition) seksen iki bölümden oluşur. Bölümlerin elli dokuzu, Şarlman'ın Papa I. Hadrian'dan aldığı Canon hukuku koleksiyonu Dionysio-Hadriana'dan büyük ölçüde ödünç alınan kısımlara da sahiptir. Ancak yasamaya yönelik kısmı gerçekten de Kralın ve danışmanlarına ait bir eserdir. Kutsal kitaptan yapılan alıntıların kapsamlı kullanımı, Şarlman'ın sarayında elde edilen kültürel gelişmişlik düzeyini ortaya koymakta ve ulaşmak istediği daha büyük hedeflere işaret etmektedir (Frassetto, 2013, s. 1). Aynı şekilde 803 tarihli kilise yönetimine yönelik çıkardığı başka bir kanunda ise rahiplerin sınavsız olarak atanmaması emredilmiştir. 813 Tours ve 847 yılında Mainz konsillerinde, rahiplerin cemaatlerinin yerel dilinde vaaz vermeleri önerilmiştir. Rahipler, yalnızca Latince bilgisi sayesinde evrensel bir kilisenin parçası olabilirken, yerel dilin kullanımı onları belli bir sınıfın insanlarına bağlı kılmıştır. Yunanca-Latince sözlükler mevcuttur, rahiplerin içinden Doğu Akdeniz'den olan kilise babalarının eserlerini ve yorumları okumak için Yunanca öğrenmiş olanlara rastlanmaktadır ancak bu oldukça nadirdir (Butt, 2002, s. 110). Görüldüğü gibi rahiplerin Kiliseye kabulü dahi Şarlman'ın yasama ile temas ettiği dini ve idari meselelerden biridir.

Frank Kilisesi üzerindeki otoritesi, babası ve amcası tarafından öngörülen ama onlarınkini hayli aşan Şarlman, konsilleri manevi meseleler üzerindeki yönetiminin sadece küçük bir parçası olarak görmüştür. 789'da Admonitio Generalis'i yayınlaması, aynı zamanda Kilise'ye yönelik yasa çıkarmak için konsillere ihtiyaç duymadığını ima eder gibidir. 800 yılının Aralık ayındaki imparatorluk taç giyme töreninden 813'teki reform konsillerine kadar, Kral yalnızca bir kaç tane sinodu ${ }^{2}$ denetlemiş ve nezaret etmiştir. Bu dönemde, önemli dini yasama faaliyetlerinin çoğunu kraliyet meclisleri üzerinden, çıkarttığ sinodlar gibi işlev gören Kilise yasaları ile gerçekleştirmiştir (Halfond, 2010, s. 156). Frank döneminde Canon; tercümesi ile Kilise Kanunu, bir sistem değildir. Aksine, dini yasa koyucuların kendi beyannamelerinin otoriter temeli olarak dayandıkları bir gelenektir. Karolenj kralları, özellikle de Şarlman, kanonik geleneği standartlaştırmak için biraz çaba sarf etmiştir ancak sonuçta çeşitliliği ortadan kaldırma ve tekdüzelik dayatma çabalarında başarısız olmuşlardır (Halfond, 2010, s. 215).

\section{Şarlman'ın Reformları, Karolenj Rönesansı ve Manastırlarda Kitap Çoğaltılmasını Yaygınlaştıran Etmenler}

Alcuin ve Theodulph'un danışmanlığı altında, Şarlman el yazması üretimini artıran yeni politikalar uygulamaya koydu. Hedefleri, klasik yazılı belgeleri kurtarmak, ayinler ve eğitimle ilgili metinleri kopyalamaktı. Bu politikalar aynı zamanda İncil gibi yeni litürjik metinler yaratmayı hedefliyordu. Fleury, Soissons ve Tour'deki Aziz Martin gibi Frank manastırlarının yazıhanelerinde el yazmaları çoğaltılmaya başlandı. Bu şekilde basit metinlerin çoğaltılmasının ötesinde Şarlman'ın saray okulu, saltanatını sanatsal bir altın çağa yükselten lüks, süslemeli el

\footnotetext{
${ }^{2}$ Hrısitiyanlıkta hakkında uzlaşma sağlanamayan veya uygulama farklılıkları bulunan durumları tartışmak ve bunlara standart uygulama ve çözüm getirmek için yapılan din adamları kurulu.
} 
yazmaları üretti (Denoël, Puyo, Brunet ve Siloe, 2018). Northumbria'lı yani Britanyalı Alcuin ile yeni bir entellektüelleşme sürecini başlatacak, onun hazırladığg programlar sayesinde İrlanda manastırlarında hüküm süren klasik dönem bilgelik eğitimiyle kendi manastırlarında yozlaşmaya yüz tutan dini eğitimi yükseltmeyi deneyecekti. Alcuin'in hazırlayacağı program özellikle manastır ve katedral okulu ve ilgili birimlerde ayrıca Şarlman'ın soylu saray yöneticileri ve özellikle de Karolenj prensler için açacağı saray okulunda uygulamaya koyulacaktı. Bu program sosyal bilimlerin atası sayılan 5. yüzyıl nesir yazarı Martianus Capella'nın Yedi Liberal Sanat'ı üzerine odaklanmıştı ve Trivium olarak adlandırılan Felsefe, Mantık ve Belagat ilimlerini takiben çalışılan Quadrivium yani aritmetik, geometri, musiki ve astronomi bilimlerinden oluşuyordu.

Alcuin, Şarlman'ın Milli Eğitim Bakanı gibi hareket etmekle kalmadı, ayrıca kilisenin litürji sistemi üzerine de çeşitli yenilikler getiren eserler de oluşturmaya çalıştı. Kendisi de bir keşişti. Latince yazdığı Alcuin İncili isimli el yazmasını ortaya koyduğu gibi çoğu Latince eserin Karolenj yazı stili (Carolingian minuscule) ile yeniden yazılarak çoğaltılmasını sağlamış; sonraları Tour şehrindeki Aziz Martin Manastırı'na başrahip olarak atandıktan sonra manastır çevresi ve manastır içi uygulamalarda eğitim düzenlemeleri yapmıştır. Buradan anlaşılacağı üzere Şarlman ile birlikte, sürece en çok katkıda bulunan isim Alcuin'dir. Kendisi, Notker, Hrabanus Maurus ve diğer isimler sayesinde Karolenj hanedanlığı sonraki nesillere bırakacağı metinlerin sayısını artırabilmiştir. Alcuin'in bizzat desteklediği el yazması üretimi ve manastırları da içeren eğitim kurumları ile ilgili düzenlemeleri sayesinde, manastırlardaki öğretim süreçlerini de değiştiren Karolenj Rönesansı, beklendiği kadar uzun ömürlü olamamıştır. Sonuç olarak, Şarlman ve Alcuin arasındaki sinerji uzun süre en üst düzeyde devam etmiştir. Bu durum entelektüel uygulamalara oldukça yansımıştır. Sonraki dönemlerde bu hareketin üzerinden fazla zaman geçmeden, torunları arasında paylaşılarak idare edilen toprak birimlerine dönüşerek gittikçe azalan zenginlik, istikrarlı olmayan bir devlet yönetimi gibi nedenlerle yok olmaya yüz tutmuştur. Aslında Karolenj Rönesansı'nın bu kadar kolay ortaya çıkması bu dönemde farklı alanlarda yaşanan kültürel ve siyasi beslenmelerle ilgili bir durumdur. Bu rönesansı fiziksel anlamda etkileyen her şeyin, Şarlman zamanındaki entelektüel girişimleri maddi olarak karşılayabilmesine katkı sağlayan siyasi başarısının ve Kilise'ye olan ilgisi ile istilaları sırasında elde ettiği zenginlik sayesinde mümkün olduğu söylenebilir.

8. ve 9. yüzy1llarda başlatılan veya onaylanan bir dizi reform daha olmuştur. Şarlman, her biri piskoposların veya başpiskoposların başını çektiği piskoposluk sistemini yeniden kurmuştur. $\mathrm{Bu}$ yapı, Roma imparatorluk hükümetinin yapısını takiben geç Roma İmparatorluğu'nda gelişmiştir; her büyükşehir, Roma hükümetinin bir merkezidir ve her büyükşehir, çevresindeki toprakları dini olarak yönetmektedir. Karolenjler için bu, sadece Kilise için açık bir hiyerarşik yapı sağlamakla kalmamış, aynı zamanda kral için bir hükümet yapısı da sağlamıştır çünkü başpiskoposlar dahil, tüm din adamları Krala karşı sorumludur.

Roma yalnızca güçlü bir dini ibadet merkezi değil, aynı zamanda Kilise Yasası metinlerinin de kaynağıdır. 'Kanonik' ifadesi, daha sonraki Orta Çağların açıkça tanımlanmış ve iyi düzenlenmiş Kilise Hukuku ile olağan ilişkisinden ayrı tutulmalıdır. Bu metinler, Frankların Roma'yı ilişkilendirdiği Hristiyanlığın parçasıdır. 747'de Papa Zacharias, Pippin'e küçük bir kanon yasası koleksiyonu göndermiştir ancak bu, 770'lerde İtalya'dan gelen metinlere kıyasla son derece mütevazidir. 774 yılının Paskalyasında, Lombard Krallığının çöküşünden 
kısa bir süre önce Papa Hadrian, Dionysius Exiguus (ö. 556'dan önce) tarafindan derlenen Kilise Kanunları -Canon- koleksiyonunun gözden geçirilmiş versiyonunu Şarlman'a hediye etmiştir. Bu versiyonun adı Dionysio-Hadriana'dır. Bu metin, Frank Krallığı'ndaki dini mevzuatın ana kaynağ1 haline gelmiş ve Admonitio generalis'te büyük bir kısmı ilan edildiğinde resmileşmiştir. Aachen'da 802 yılında yapılan sinodda bazı bölümleri yüksek sesle okunmuş ve yorumlanmıştır. Şarlman zamanında yeni ele geçirilen prensliklerde el konulmuş, hepsi siyasi hizmetlerin emrinde olan pek çok mülkiyet ve ayrıca krallığın birikmiş bir hazinesi vardır. Önemli piskoposluklar ve büyük manastırlar gibi Kilise mülkiyetlerinin bir kısmı, siyaset dişındaki hizmetler için ayrılabilmektedir. Aslında bu kaynaklar, civar noktalardan hatta İspanya ve İngiltere'den bile şair ve akademisyenleri, teolog ve öğretmenleri ülkeye çekmek ve Şarlman'ın sarayındaki entelektüel halkada daimî olmalarını sağlamak için kullanılmıştır. Yeni kazanılan bu servet Karolenj Rönesansı'nı mümkün kılmıştır: sadece dışarıdan insan çekmeyi değil aynı zamanda Kralın lüks el yazmaları elde etmesini de sağlamıştır (Fichtenau, 1978, s. 82). Bu noktaya kadar sürekli kullanımda olan Merovenj litürji metinleri muhtemelen artık geçerliliğini kaybedecektir. Bu nedenle çoğaltılmaktan çıkmıştır. Merovenj el yazmalarından hiçbirinin 8. yüzyılın üçüncü çeyreğinden öteye geçememesinin nedeni bu olabilir. Merovenj litürji uygulamaları, Şarlman'ın ayin reformlarının bir parçası olarak 'Roma' litürjisi (en azından Roma'ya ait olarak algılanan ayinler) ile değiştirilmiştir. Bununla birlikte, Karolenj döneminde litürjisi, Merovenj Frank ayinleri veya dualarından uzaklaşmamıştır (Hen, 1995, s. 60).

\section{Kütüphaneler ve Karolenj Manastırlarında El Yazmalarının Çoğaltılması}

Karolenj Rönesansı zamanında manastırlar, sağlam bir şekilde kurulmuş güç merkezleri gibidir. Her birinin bir yazıhanesi vardır ve birçoğu klasik metinlerin hayatta kalan son örneklerini aktif olarak çoğaltmaktadır. Yazıhaneler, Şarlman'dan önce Autun, Luxeuil, Corbie, Aziz Denis, Fleury-sur-Loire, Tours Aziz Martin, Fulda gibi yazı atölyeleri büyük tüm manastırlarda ve birçok piskoposlukta mevcuttur (Hildebrandt, 1992, s. 74). Aslında, Klasik Latince metinlerin büyük bir kısmının aktarımını Karolenj yazıhanelerinde yapılan çoğaltma işine borçluyuz. Önce Başrahip Maurdramnus zamanında Corbie Manastırı ve Alcuin yönetimi altında Tours Manastırı'nda yaşayanlar gibi bazı kâtipler harflerinin yazım şekilleri ve bir yazım stili geliştirme ve standardizasyonunu sağlama konusunda büyük etki yaratmıştır. Corbie Manastırı, Karolenjlerden önce gelen Merovenj hanedanlığ 1 zamanında litürjinin en otoriter merkezi konumundayd. Yazıhaneler ve okullar da katedrallerin bünyesinde daha sık yer almaya başladı, çoğunun bir okulu ve arşiv dairesi oluyordu.

Karolenj hanedanları için manastırlar oldukça önemlidir. Manastırlar ailenin ilgisinin veya zenginliğinin bir parçasıdır ve ilk Karolenj Arnulf (7. yüzyıl hanedanı) gibi birçok hanedan üyesi saray yöneticisi, önce piskopos, sonra da aziz olmak üzere bir kilise kariyerine sahip olmuştur. Manastırlar, müttefikleri veya yöneticileri işe almak için eğitim kurumları olarak görülüyordu. Manastırlarla ilişkilendirilen zenginlik ve toprak, sadık destekçilere verilecek çok önemli ödüllerdi (Hildebrandt, 1992, s. 51-52). Tüm bunlara ek olarak Şarlman'1n kiliseleri merkez alan reformuyla birlikte kilisenin ve manastırların önemi artmış; manastır kütüphaneleri kitaplarının sayıca artması ve işlemeli, değerli mücevherlerle bezenmiş olması noktasında zenginlikleri ile bilinir olmaya başlamıştır. 


\section{Karolenj Kütüphanelerindeki Kaynaklar ve Kütüphane Kolleksiyonlarının İçeriği}

Karolenj hanedanlığı ve dönemini diğer Frank hanedanlıkları ve dönemlerinden ayıran en önemli özelliklerden biri de entelektüel yenileşme çalışmalarına paralel olarak kütüphanecilikte ön plana çıkan çabaları ve el yazması eserlere olan düşkünlükleridir. Bir müddet sonra hanedanlık, el yazmaları konusunda o kadar ilerlemiştir ki kütüphaneler gitgide genişlemeye, hatta eser türlerindeki zenginlikten dolayı her kütüphane kendi kodekslerini oluşturmaya başlamıştır. Kitaplar belli bir sıraya göre tasnif edilmekte, belli özelliklerine göre seçilip çoğaltılmakta, daha sonra kitap listeleri yani kodeksler oluşturulmaktaydı. Hazırlanan kitap listelerine göre kütüphane bölümleri düzenlenmekte veya raflar gruplandırılmaktaydı. İşte bu durum Orta Çă̆ Avrupası için kütüphanecilikte Karolenjlerin yeni bir çığır açtığını göstermektedir. Dönemin entelektüel birikimi ve çalışılan eserleri hakkında bilgi edinmek istenirse bu kitap listelerini incelemek yeterli olacaktır. Çalışmanın ilerleyen kısımlarında dönemin önde gelen el yazmalarına yer verilmiştir.

780'li yıllarda krallık boyunca kütüphaneler kurulması için açıkça ifade edilen bir politika yürürlüğe girmiştir. Katedral ve manastır kütüphanelerindeki mevcut eserlerin, yazıhanelerde oldukça düzenli bir şekilde çoğaltılması, yeniden düzenlenip genişletilmesi gerekmekteydi. Bu yeniden düzenleme ve genişletme işlemi sorunsuz ve devamlı değildi fakat birkaç yüzyıl içinde Karolenj yazı stilinin de faydası ile tüm krallığa yayılmıştır. Bu hareket, saray için eğitimli yöneticiler sağlamak, kralıkta hızla yayılan Hristiyanlığı güçlendirmek ve geçmişe ait eserleri korumak için başlatılmıştır (Butt, 2002, s. 189). Karolenj Rönesansı ve hemen öncesini de içince alan bir dönem olarak kabul edilebilecek bir süreçte, el yazmalarının çoğaltılmasını kolaylaştırmak amacıyla yeni bir yazı stili ortaya çıkmaya başlamıştır. Tekdüzeliğin getireceği kopyalama rahatlığı sayesinde kitap çoğaltma faaliyetleri hız kazanmış; yapılan nüshaların imparatorluğun çoğu bölgesindeki din adamları ve okuryazar kişiler tarafindan rahat bir şekilde okunmasının önü açılmıştır. Karolenj yazı stili ortaya çıktığı toprakları aşıp günümüz yazı stiline zemin oluşturarak en azından Latince alfabe temelinde köklü değişikliklere uğramadan çağlar içinde kendini muhafaza etmeyi başarmıştır.

Dönem içinde bu bilgiyi sağlayan en somut veriler Fulda, Würzburg, Aziz Wandrille kütüphaneleri ile bizzat Şarlman'ın kendi bireysel kütüphanesinde biriktirdiği kitapları listeleyen el yazması kodekslerdir. ${ }^{3}$ Bunların bir kısmı okunamaz halde olsa da sayfa sayılarından kütüphanede oldukça fazla sayıda kitabın olduğu anlaşılmaktadır. Okunabilen kısımlardan ise kütüphanelerin tema olarak genellikle dini risalelerle ön plana çıktığ görülmektedir. Eski ve Yeni Ahit'ten alıntılar, Efes'teki Yedi Uyurlar, Aziz Paul'ün Vahiyleri, Büyük Gregory'nin Vaazları, erken dönem kilise papazlarının eserleri gibi dini içerikli eserlerin yaygın olduğu görülebilmektedir. Şarlman'ın koleksiyonu o kadar zengindi ki bazen okullar ve saray okulu onun kütüphanesinden kitap ödünç dahi alabilmekteydi. Bu kütüphanelerin kapsamlı birer kütüphane veya zengin birer misyoner kitaplığı oldukları söylenemez. Ancak İncil kitapları, Aziz Gregory'nin Vaazları ve azizlerin yaşamlarından seçmeler Hristiyanlı̆̆ın yerleşmesi için temel malzemelerin bir kısmını oluşturmaktaydı (McKitterick, 1989, s. 170). Eserlerin ezici bir çoğunluğu dini içerikli olsa da bu hareket din adamlarına ek olarak aristokrat

\footnotetext{
${ }^{3}$ Bir eser veya doküman oluşturacak şekilde yazılmış veya yazılabilir haldeki materyallerin bir araya toplanması ile elde edilen kitap formatıdır. Tarih boyunca ele geçen eski örneklerde kağıttan, papirüs ve parşömene kadar çeşitli malzemelerden oluşmuş el yazması kodekslerin olduğu bilinmektedir.
} 
ve laik sınıfı da içine aldığı için Hristiyan eserlerinin dışında seküler türden birkaç eserin de sıklıkla okunup çoğaltılmaya çalışıldığı doğrudur. Manastırların en önemli yönlerinden biri, el yazmanlarının çoğaltıldığı yazıhanelere sahip olmasıydı. El yazması parşömenlerinin nasıl yapılacağı ve yazı yazma öğretimi ciddi bir uğraşı gerekli kılıyordu. Karolenj manastırları ve onların ürettiği yazmalar sayesinde, birçok klasik ve yeni eser kopyalandı ve çoğaltıldı. Bu da çok sayıda eğitici metin ve kitaba sahip olmak anlamına geliyordu. Ancak en önemlisi Kutsal İncil ve mezmurların kopyaları eğitim amaçlı kullanım için yeterli sayıda bulunmasıydı. Bu nedenle Kutsal metinlerin çoğaltılması ve yazımı için verilen eğitim çok ciddiye alınmıştır. Kutsal Yazıları incelemek ve anlamak zamanla Karolenj eğitiminin nihai hedeflerinden biri haline gelmiştir. Yine, listelerden de anlaşılabileceği gibi kütüphane oluşturulurken takip edilen birtakım yollar, eser seçiminde belli kriterler vard1 (McKitterick, 1989 s. 194). Yenileşme hareketi manastır yazıhanelerinde çoğaltılan el yazması eserler üzerinden vücut bulduğu için kitap seçimleri genellikle İncil kitapları, Eski ve Yeni Ahit kitaplarından, azizlerin bazen de azizelerin hayatı ve ilgili risalelerden, sonrasında daha genel başlıklardan oluşuyordu. McKitterick'in (1989) belli başlı manastırların ve rahiplerin kütüphanelerinden yaptığı sınıflamayı özetlemek gerekirse manastırların kitap toplarken tercihlerinin şu şekilde olduğu düşünülebilir:

1. İncil Kitapları

2. Eski ve Yeni Ahit kitapları

3. Mezmurlar ve ayin kitapları

4. Azizlerin hayatları ve yaşamlarından risaleler

5. Gerome, Basil, Cassiodorus, Boethius, Bede, Sevillalı Isadore, Donatus, Virgil, Cicero, vb klasik dönem yazarlarının eserleri (Bazı manastırlar belli bir yazarın eserlerini kendine milat seçip sonrasında ortaya çıkmış eserleri kütüphanelerine kabulde seçici davranabiliyordu. Mesela Aziz Gall Manastırı, kütüphanesi için eser toparlarken Bede'den sonraki yazarların eserlerini tercih etmemiştir. Dönemin yenileşme hareketine yön veren isim olan Alcuin'in Bede'in öğrencisi olmasının da bu durumun üzerinde etkisi olabilir.)

6. Kilise'nin başrahibi veya o manastır içinde nüfuzlu rahiplerin o dönemde yazdığı eserler

7. Tarih, kültür, biyografiler vs. gibi çeşitli alanlara ait dini içerikli olmayan belli başlı eserler

8. Manastır öğrencileri için ders kitapları (özellikle dönemin önde gelen saray eğitmenlerinden Alcuin, Hrabanus Maurus, Orleanslı Theodulf gibi isimlerin çeşitli konulardaki fikirlerini içeren açıklamalı yazılar).

9. Ayrıca ilahiler, Hristiyanlığa yönelik manzum eserler, bilinen şiirler, vs.

Daha genel bir sınıflama yapacak olursak Karolenj kütüphanelerindeki eserlerin yazım, teoloji, uygulamalı bilgiler, ayin bilgisi, riyazet, ĕgitim bilimi, dini yaşamın gerekleri gibi konu başlıkları üzerinde gruplandığını söyleyebiliriz. Peki, başrahipler veya kütüphaneden sorumlu kişiler kütüphaneleri için hangi kitabı seçeceklerini veya çoğaltmak istedikleri eserin mevcut olup olmadığını nereden öğreniyorlardı? Cevabın diğer büyük kütüphanelerin kitap listesi olduğu tahmin edilebilir. "Roma ve Monte Cassino gibi büyük kütüphanelerdeki eserler Aachen'daki saraya veya ilgili manastır yazıhanesine getiriliyordu. Bu eserler çoğaltılınca Tours, Orleans, Salzburg ve Lyons gibi içeriklerinin, yazı formları ve dizaynları ve görsellerinin 
kopyalanacağı diğer manastır merkezlerine gönderiliyordu" (Avrin, 2010, s. 244). Ayrıca belli başlı eserlerin içinde zaten okunması gereken eserlere dair atıflar mevcuttu. Mesela 5-6. yüzyılın ünlü akademisyen ve devlet adamı Cassiodurous'un Institutiones isimli eserinde yazım bilgisi için okunması gereken bir dizi eserin adı vardır. Öğretimini belli alanda derinleştirmek isteyen kütüphaneler bu eserlerde geçen diğer eserleri ilgi alanları ve kullandıkları sisteme göre temin edebiliyor, söz konusu nüsha sahibi ile fazla nüshayı başka bir eserle değiş tokuş edebiliyor veya diğer kütüphanelerden geçici süreyle temin edip yazıhanesinde bir nüshasını çıkarttırabiliyordu. Elbette bu, söz konusu manastırların paylaşıma ne kadar açık olduğu ile ilgili göreceli bir durum da olabilirdi.

Eserlere ulaşmak ve kopyalamak oldukça zahmetli bir iş olduğu için manastırlar kitaplara ulaşım konusunda oldukça tutucu bir tavır sergiliyorlardı. Aziz Gall Manastırı, kitaplarını kimin ödünç alabileceği konusunda oldukça seçiciydi çünkü çok kıymetli antik dönem eserlerini muhafaza ediyordu ve el yazmaları özellikle de süslenmiş ve değerli mücevherlerle kaplı ise oldukça kıymetli bir eşya niteliği taşıyorlardı. Kraliyet hamiliğindeki manastırlarda el yazması eserler ve antik dönem eserleri oldukça zengin koleksiyonlar halindeydi çünkü bu el yazmalarının maddi açıdan külfeti çoktu ve yazıhanelerdeki üretim süreci mürekkebinden parşömenine kadar oldukça maliyetliydi. Bu nedenle Aziz Gall ve Lorsch gibi kraliyetten aldığ1 maddi destek yüksek olan manastırların kütüphanelerinin de zengin olduğu tahmin edilmektedir.

Kiliseye ait kütüphanelerdeki kitap sayısı bu çaba sayesinde artmıştır. Şarlman'ın bu kitap sevgisi daha sonra da devam etmiştir. Onun yönetimi altında, her manastırda çok sayıda yazman işe alınmış, böylece yazıhane ve yazı odaları sadece kendi kütüphanelerine değil artan kitaplarla diğer manastırlara da kitap sağlamıştır. Kütüphane listeleri ve el yazmaları, Karolenj koleksiyonlarının kutsal ve pagan inanca ait olmak üzere şaşırtıcı derecede çok sayıda kitap içerdiğini kanıtlamaktadır (Rowling, 1973, s. 27). Şarlman'dan önce 400-700 yılları arasındaki dönemden kalan el yazması sayısı 500 civarındadır fakat onun krallığı döneminde sayı artırılmış ve yapılan yeni düzenlemelerden sonra kitap sayısı 1000'e kadar yükselmiştir. Onun döneminde ve M.S. 950'li yıllara dek üretilen el yazmalarının sayısı 7000'e ulaşmıştır. Bu dönemde İngiltere'nin kuzeyindeki manastırların bünyesinde ve özellikle eski Yunan kültürünün orijinal eserlerini ve eğitim kültürünü muhafaza etmiş olan İrlanda'da, keşiş ve rahiplerin klasik eserlerin el yazmalarını devamlı olarak okuyup çoğalttığı yazıhaneler bulunmaktaydı. Krallık, bu yazıhanelerle iletişime geçmiş ve bu dönemde yaşayan gezgin Hristiyan misyonerler sayesinde Karolenj eğitiminin içeriğini zenginleştiren kitap alışverişleri olmuştur.

Rahip eğitimini düzenleyip, siyasi açıdan kabul gören başrahipleri göreve geçirmesine ek olarak Kral, danışmanı Alcuin'in de yardımı ile yerel manastırları Latin metinlerinin standart hale getirilmesi için görevlendirmiştir. İncil'in ve çeşitli ayin kitaplarının yeniden gözden geçirilmesine, yaşayan tüm eserlerin her haliyle kopyalanıp korunması ve yukarıda bahsedilen Karolenj minüskülünün, Merovenj yazılarından daha üniter ve okunaklı hale gelecek şekilde mükemmelleştirilmesi eşlik etmiştir. Nitekim, Karolenj yazı stili olan Karolenj miniskülü, dini ve kültürel hayatın standart hale getirilmesinin bir sembolü olmuştur (Hildebrant, 1992, s. 74). Karolenj miniskülü hem yazının standart hale getirilip daha rahat okunması hem de klasik dönem eserlerinin çoğaltılmasında kolaylık sağlamıştır. Bu ayrıca Latince'ye bağlı olarak atılan 
önemli bir adımdır. Söz konusu yazının kullanımı o kadar yerleşmiştir ki dönemi takiben, İtalyan Rönesansı'na değin hatta bu Rönesans dönemi boyunca da takdir edilip kullanılmıştır. 16. yüzyıl başlarında matbaalar, ilk basım yapıldığında Karolenj yazı stiline itibar edip uygun kalıplar çıkarmışlardır. Karolenj miniskülü önceden kullanılan majiskül yani büyük harflerden ibaret yazı gibi kullanışsız değildi, pratik ve daha okunaklıydı. Gotik yazı stilini geride bırakarak uzun yıllar boyunca etkin olmuştur. 9. yüzyılın başlarında, kitaplar ve kitap üretimi, Karolenj Avrupası'nda kültür ve eğitim hayatının önemli bir parçası olmuştur, ancak aynı yüzyılın sonlarında Viking baskınlarının ortaya çıkışı Avrupa'yı parçalamış ve kitap üretimi ciddi şekilde kısıtlanmıştır.

Sonuç olarak bu girişim Şarlman'ın ruhban sınıfını hedef alarak başlattığı bu yenilenme hareketi kütüphaneleri hedef almıştır. İçerik olarak da yenilenmesi veya yeniden zenginleşerek düzenlenmesi gereken kütüphaneler Aristo ve Plato'nun yazı ve diyaloglarını, eleştirilerini, Marius Victorinus'un yaptığ 1 çeviri ve derlemeleri, Cicero'nun eserlerinin yanı sıra Aziz Augustine'in çalışmalarını, vb. içerecektir. Augustine'in ve hemen hemen herkesin o zamanki algısına göre İncil, kelimenin tam anlamıyla her açıdan mükemmel bir anlam ifade eden bir metin değildir. İncil onların gözünde daha çok Tanrı'nın kendileri için hazırladığı yaşam kitabından ibarettir, ancak yorum gerektirmektedir. Dolayısıyla İncil sadece edebi bir metin değil, aynı zamanda mecazi ve kehanetler içeren bir metindir. Gerçekten ne anlama geldiğini, gerçek mesajlarının ne olduğunu anlamak için matematik, astronomi, geometri, hatta müzik gibi konuları ve kesinlikle gramer, retorik ve mantık bilgisi gerektirdiği düşünülmüştür. Bunlar ise Cassiodorus'un müfredatının Yedi Liberal Sanat'ının bileşenleridir. Kütüphanelerin fiziksel kapasiteleri ve bu işe harcadıkları zaman arttıkça ve akademisyenler de değiştikçe eserlerin türleri de artmıştır. Edebi eserlere ek olarak öğrenilenler, derlemelerden ve geçmişe ait bilgi ansiklopedilerinden edinilmiştir. İçlerinden en popüler olanlarından biri, 7. yüzyılda, akademisyen bir piskoposa, Sevilla'l1 Isadore'a ait olan Etimoloji idi. Bu eser, her konuda bilgi içeren bir ansiklopedi idi ve tüm sanat alanları, bilim, tarih ve teoloji de dahil olmak üzere her alana hitap ediyordu (Claster, 1982, s. 131). Bu çalışma okuyucunun konuyu daha iyi algılayabilmesini amaçlayan terimlerin gerçeğe dayalı olmayan türevlerinden ibaretti. Karolenj hanedanlığı döneminde doğal felsefe olarak geçen yazın türü ansiklopedilerdi. Bunlar aslında bilgi toparlamaları, söylenti ve akademisyenlik şeklinde bir gelenekti. Bir ansiklopedideki bilgi doğrudan kendinden önce yazılmış başka bir ansiklopediden taşımaydı. 8. ve 9. yüzyıldaki en etkili yazarlar Boethius, Cassiodorus, Sevilla'lı Isadore ve Muhterem Bede idi. Boethius sosyal bilimlerdeki dört bilimin hepsine dair bölümler içeren en iyi ansiklopedileri oluşturmuştur. Cassiodorus (c.490-c.585), Kutsal ve Beşerî Okumalara Geçiş ("Introduction to Divine and Human Readings”)'te fen bilimi de dahil olmak üzere dört sosyal bilimin hepsiyle ilgili yazmıştır (Butt, 2002, s. 139).

\section{Karolenj El yazmalarının Özellikleri ve Şarlman Döneminde Önde Gelen Ekollerden Örnekler}

6. ve 8. yüzyıllar arasında Batı Avrupa el yazmalarında ortaya çıkan bir özellik olan sahneli, ayrıntılı ve dekore edilmiş baş harflerin kullanımı, 843'te Ortodoksluğun İkonoklazma karş1 nihai zaferinden sonra Bizans'ta benimsenen bir dizi sanatsal fikirden olmuştur. Bu kullanımın Batı'dan Doğu'ya bu aktarımı tespit etmek imkansızken, İtalya'da Yunanca kullanan manastır yazıhanelerinin buna aracılık ettiği gibi bir durum da ortaya konabilir. Roma'da 8. yüzyılın 
sonlarında veya 9. yüzyılın başlarında yazıldığı düşünülen bir dizi Latince el yazması incelendiğinde, kuzeydeki Hiberno-Sakson ve Merovenj yazıtlarında meydana gelen gelişmelere olan ilginin uyanmakta olduğunu görülebilir (Osborne, 1990). Baş harf kullanımındaki bu süsleme eğiliminin yanı sıra Karolenj dönemi el yazmalarında özellikle resimlendirme üslubu Karolenj rönesansının en büyük getirisi olan Karolenj minüskülünün el yazmalarında kullanılmasıdır. Bu dönem özellikle Şarlman'ın saray okulunda ortaya çıkan el yazması ekolleri ile kendini başka bir boyuta taşımıştır. Eserlerde Bizans, Klasik dönem el yazmaları ve Hibernosakson dediğimiz (özellikle 7. yüzyılda yaşamış) Güney İngiltere Anglosaksonlarının süsleme ve resimleme alışkanlıklarının harmanlanarak ve yıllar içinde git gide gelişerek kendi türünü yarattığı görülmektedir. Karolenj el yazmalarının, büyük ölçüde ya da tamamen din adamları tarafından, Karolenj İmparatorluğu çevresinde birkaç atölyede üretildiği ve her birinin belirli konum ve zamanın sanatçılarına ve etkilerine dayalı olarak geliştirilen kendi üslubuna sahip olduğu varsayılmaktadır (Dodwell, 1993). Bu dönemler sadece Şarlman zamanıyla sınırlı olmayıp torunu Kral Dazlak Karl'ın saray okulu zamanına kadar uzanmaktadır.

El yazmalarında, onları kimin görevlendirdiğine ve hangi kiliseye veya manastıra verildiğine dair yazılar mevcuttur. Ancak bunları üretenlere ilişkin tarih veya isim bilgisine nadir rastlanmaktadır. İlk atölye Şarlman saray okulu bünyesinde başlatılmış daha sonra Karolenj döneminin önde gelen ekollerinden Rheims; Tour stili, Şarlman'ın evlilik dışı oğlu olan Drogo'nun başrahip olduğu manastırdaki Drogo tarzı; ve son olarak torunu Dazlak Karl'ın zamanındaki saray ekolleri doğmuştur. Bunlar büyük merkezlerdir, ancak burada üretilen sanat eserleriyle karakterize edilen diğerleri mevcuttur. Saray ekolü el yazmaları oldukça kıymetli mücevherat ile süslü ve gösterişlidir. Roma klasisizminin yeniden canlandırmayı başarmış yine de hacim ve mekânsal ilişkilerle ilgilenmeden temelde doğrusal sunumlarında Merovenj ve Hibernosakson geleneklerini sürdürmüşlerdir.

Karolenj el yazmaları, Karolenjlerin Klasik Dönemle olan özel ilişkisinin de altını çizmektedirler. Antik emsalleri örnek olarak kullanmaları, onların uzak bir entelektüel dünyayla anında temas kurmalarını sağlamıştır. Ellerindeki metinleri korumuş ve gördükleri metinlerin aslına uygun kopyalarını yaparak sonraki dönemlere iletmişlerdir. Bunlar, görünüş olarak, kendi çağdaş Karolenj 'minüskül' el yazısı biçimlerinde üretecekleri kitap türlerinden muhtemelen çok farklı niteliktedir. Başlangıç olarak, eski örneklerde farklı alfabeler kullanılmıştır. Bunlar rustik karakterde ve kare büyük harflerle, yuvarlak majüskül ve yarı yuvarlak olanlarla yazılmış eserlerdir. Karolenj kopyalarının düzeni standartlaştırılarak uyarlanacak ve çağdaş Frank okuyuculara yardımcı olmak için noktalama işaretlerinin kullanımında değişiklikler yapılacaktır. Bu şekilde, Frank yazmanlar, antik çağın uzak entelektüel dünyasını çağdaş bir izleyici için erişilebilir hale getirmiştir. Bu nedenle, el yazmaları, içerdikleri metinler kadar, hizmet ettikleri metin gruplarını ve kimliğini ifade ettikleri kişileri ortaya çıkaracak niteliklere sahiptir (McKitterick, 2004, s. 38).

El yazması eser üretmek Karolenj döneminde oldukça kutsal bir görev olarak algılanıyordu çünkü temelleri antik dönemin klasik eserlerine dayanan Hristiyan dünyasındaki bu yenilenme kendini el yazmalarına verilen önem ile ön plana çıkarmıştı. El yazmalarının yapımı manastırlarda daha evvelki hanedanlıkların yönetimi zamanında da oldukça ciddiye alınıyordu, yazman keşişlerin yazıhanelerde kutsal kitap kopya ederek geçirdiği vakitler 
amelleri açısından da önemliydi. Yine manastırlar tercümelerin de yapıldığı akademik yanı olan kurumlardı. O dönemde düzenli eğitimi sağlayan tek kurum olmaları açısından bu durum olağandı. El yazması eser çoğaltmak manastır hayatında rahiplerin ve keşişlerin kutsal görevlerinden biriydi ve düşünülenin aksine yalnızca eldeki metne bakıp kopyalamaktan ibaret değildi.

Buradan hareketle zaten kutsal bir uğraş olan rahipliğin gerekleri üzerine ayrıca el yazması üretmek, dönemin yazman rahipleri için yapılabilecek en kutsal işlerden biriydi. Yazmanlar oldukça titiz yazı eğitimlerinden geçiyordu çünkü zaten bol bulunmayan ve kolay elde edilemeyen parşömenler kıymetliydi. Rengine göre esere anlam kazandıran mürekkebin ehil ellerde kullanılması; bu ellerin sahibi kadar okuduğunu doğru olarak anlamlandırıp aktarabilecek dikkatli zihinlerin okuyacağı eserlere dönüşmesi gerekiyordu. Kaldı ki; daha önce de belirttiğimiz gibi Karolenj Rönesansı'nın temel hedefi bilge keşişler yetiştirmekti ve bu keşişlerin ihtiyacı olan şey tam da buydu: iki cilt arasındaki bilgi. Parşömenler manastırlarda kuzu derisinden oldukça zahmetli bir şekilde bizzat rahipler tarafından üretiliyordu.

Karolenj el yazmaları diğer türlere göre çok daha ihtişamlı ve gösterişlidir. Hatta Karolenj yazıhaneleri bu konuda oldukça cömert bir tavır sergilemiş tıpkı takı yapımında mücevherat kullanmaktan kaçınmadıkları gibi kitap ciltlerini de adeta birer takı eşyası gibi süslemişlerdir. El yazmalarında süslemelere renk vermek için varak kullanımının yanı sıra kimi kıymetli eserlerde mürekkep yerine altın da kullanılmıştır. $\mathrm{Bu}$ yazmaların çoğu mora boyanmış parşömenlerin üzerine çalışılmıştır ve görseller başka bir deyişle resim işçiliği bakımından da oldukça zengindir. Bahsi edilen bu mor boya, Britanya'nın etrafındaki denizlerde bir deniz salyangozu türünden elde edilmekteydi. Ayrıca Güney Avrupa'da meşe ağacının üzerinde yaşayan kermes adı verilen bir böceğin kurutulmuş yumurtalarının yardımı ile de sağlanabiliyordu. Bu yumurtalar şap, meyve suyu, kurşun, ahşap tozu, sıvı dışkı ve asetik asit ile karıştırıldığında, parşömenin özelliklerine de bağlı olarak, parlak kırmızı veya kırmızıdan mor renge kadar, pembe ve mavinin farklı tonlarını sağlayabiliyordu. Bu şekilde yazım işlerinde mürekkep olarak kullanıldığı bilinmektedir (Loveluck, 2013, s. 22).

Minyatür ve yazıların mor renk parşömen üzerine işlenmesi, el yazmalarını hükümdarların görkemli bir şekilde dini kurumlara bağışladığı uzun bir himaye geleneği girişimi olarak da algılanabilir. Nihayetinde geç antik dönem uygulamalarından kaynaklansa da altın ve gümüşle yazılmış mor parşömen sayfalarından lüks kodeksler oluşturuluyordu. $\mathrm{Bu}$ türden hediyelerin Karolenj hükümdarlarla bağdaştırılması tüm kuzey ve doğu Fransa bölgelerinde yaygındı (Kitzinger ve O'Driscoll, 2019, s. 235). Karolenj dönemi el yazmalarının karakteristik özelliklerinden biri de fil dişi oyma tasvirler içeren ön ve arka panel/kapaklarıdır. Bu dönemden önce fil dişi ticareti 6. yüzyılda neredeyse durma noktasına gelmişti ve sanat eserlerinin çoğunda bu malzeme kullanılır halde değildi. Seküler Roma panellerini kullanan Karolenj el yazması süsleyicileri sanatlarını uygulayacak yeni bir alan bulmuşlardı (Schutz, 2004, s. 282). Bu paneller İncil veya diğer kilise kitaplarından sahneler, evanjelist azizler, ruhani varlıkların temsilleri ve sembollerle süsleniyordu.

$\mathrm{Bu}$ el yazmalarında yazıda olduğu kadar kitabı görsel anlamda zengin göstermenin de yolları aranmış ve bunun için de maddi anlamda büyük harcamalar yapılmıştır. Özellikle aşağıda bahsedilecek olan saraydaki Ada okulunun meşhur Godescalc yazmaları bu konuda zamanının örneklerine göre oldukça ön plandadır. Aslında bu yazmalardaki mor üzerine altın 
ve gümüş kakma süslemeler Bizanslı yazmanları örnek alınarak yapılmıştır. Yine görsel amaçlı çalışılmış öğelerden hayat çeşmesi figürü de Bizans orijinli bir öge olup tasviri Karolenj dönemi içinde detaylandırma ve arka plan isimlere yapılan vurgu açısından değişiklik göstermektedir. "Godescalc yazmalarında başka stil ve ikonografi kaynakları da vardır: kral tacı giymiş İtalyanlaştırılmış Hz. İsa figurü, dekoratif kenar ve çerçevelerde Hiberno-Saxon, yani Erken dönem İrlanda ve İngiltere bölgesine ait örgü ve desenler, Süryani el yazmalarda görülen bitki ve hayvanlar gibi (Avrin, 2010, s. 244).

Karolenj dönemi, kendinden önce gelen Merovenj hanedanlığından öğrendiği şeylerden ve özellikle el yazması üretiminin izlerinin çok olduğu 4. ve 6. yüzyıllar arası dönemde bu konuda edinilen bilgi birikiminden istifade etmiştir. Tüm bunlara kendisine ait yeni uygulama ve yazım tekniklerini de ekleyerek kendi üslubunu ortaya koymuştur. Karolenj yazı stili ifadesi her ne kadar bu türün Şarlman'ın veya rönesansının planlayıcısı ve yönetici olan Alcuin'in aktif oldukları dönemin adı ile anılsa da aslında farklı stillerin ekollerinden, belirli dönemler boyunca etkilenerek ortaya çıkmıştır. Tour ve Corbie Manastırlarında kitap çoğaltımında daha evvel kullanılmış olan stillerden etkilenildiği bilinmektedir. Kendinden hemen önce kullanımda olan yazım stilinin Merovenj yazısından farklı olduğu göze çarpar. Aslında Karolenj Rönesansı'nda büyük bir etki ile ortaya çıkmış gibi görünse de bu dönemden hemen önce 780'li y1llarda Corbie Manastırı'ndaki el yazmalarında ortaya çıkan stil, özünde ve tekabül ettiği dönem itibariyle Karolenj yapıdadır. Buna ek olarak Şarlman'ın asıl yeri Aachen, bir diğer adı ile Aix şehrinde saray okulunda (schola Palatina) yazılan eserlerde tam anlamıla Karolenj stiline de rastlanmaktadır. Bu okul Şarlman ile seyahatlerinde dahi onunla gezen, imparatorun bizzat sarayına eğitim vermesi için davet ettiği alanında meşhur Frank/yabancı din adamları ve alimler ile aile bireylerinden oluşmaktadır. Burada okul ifadesinden anlaşılması gereken, Kral ile birlikte bulunup onunla eğitim alan ailesi ile bir grup saraylı ve asilzadedir. Okul, Alcuin tarafından yönetilmiş, daha çok Trivium ve Quadrivium ilimlerinde tartışmalara eğilim göstermiştir. Latince Antik Dönem Yunan ve Roma eserlerinin de okunduğu okulda her bir öğrencinin Antik Dönem kahramanlarından veya İncil'den alınan takma isimlerle söz konusu alanlardaki entelektüel tartışmaları gerçekleştirdiği bilinmektedir. Alcuin hizmetinin son zamanlarını geçirdiği ve başrahiplik yaptığı Tour Manastırı'nda bulunduğu süre içinde de oldukça etkili olmuştur ${ }^{4}$.

Temel olarak Karolenj dönemi el yazmaları Saray Ekolü, Reims Ekolü, Tours Ekolü, Metz Ekolü ve ilerleyen dönemlerde Dazlak Şarl'ın saray ekolü başlıkları altında incelenmektedir.

Bu dönemde saray ekolü veya diğer adı ile Ada Yazmaları (Ada Gospels) olarak bilinen bir dizi el yazmasına günümüz tarihçileri Ada Ekolü/Ada Okulu adını vermiştir. Bu saygın yazman grubunun Soissons, Harley Golden, Lorsch, Godescalc Yazmaları gibi ünlü birkaç eseri daha vardır. Bu okulun en önemli özelliği Karolenj yazı stili ile süslemeli kitaplar üretmesidir. Şarlman'dan sonraki hükümdar oğlu Dindar Louis zamanında ise bir rahibe hediye edilmek üzere yazdırdığı Ebbo Yazmaları da önemli bir örnektir ve ikinci bir ekol olarak değerlendirilebilir. Ayrıca stil ve ikonografi açısından diğerleri için örnek teşkil etmiştir. 9. yüzyılın başlarında, Hautvillers'de (Rheims yakınında) Rheims Başpiskoposu Ebbo'da

\footnotetext{
${ }^{4}$ Şarlman'ın saray okulu ve bu dönemde eğitim hakkında daha fazla bilgi için bkz. Erkoç, S. (2014).
} 
sanatçıları bir araya getirdi ve Karolenj sanatını neredeyse tamamen değiştirdi. Ebbo'nun Gospel kitabı (816-835), klasik Akdeniz formlarında bilinmeyen bir ilham ve enerjiyi çağrıştıran hızlı, taze ve canlı fırça darbeleriyle boyanmıştır. Rheims okuluyla ilgili diğer kitaplar arasında, belki de tüm Karolenj el yazmalarının en önemlisi olan Utrecht Psalter bulunmaktadır. Karolenj döneminde katipleri Evanjelistler olarak gösteren tüm sayfa tasvirler ve kanon listelerinin mimari yapı resimleri içinde verilmiş süslemeli sunumu geleneği devam etmiştir. "Metin sayfalarında kitap süsü olarak İncil kitaplarından temalar işlenmiştir; betimlenen bu sahneler küçük olsa da 1şık ve gölgelerle ayarlanan figürler sayesinde üç boyutlu izlenimi verir. Fakat sayfanın genel görüntüsü düz ve dekoratiftir" (Avrin, 2010, s. 244). Karolenj el yazmalarının bazılarında paragraf başlarındaki kelimenin ilk harfini büyük yazmak ve İncil'deki bazı olayları büyük harflerin içinde resmetmek de yukarıda bahsedildiği gibi bir yazım geleneğidir. Bu ekollere Tour ve Metz manastırlarında doğan ekolleri eklemek de mümkündür.

Kitaplar için görsel çizimi ve resim yapma işlemi de tıpkı yazım işlemi kadar ciddiye alınmış hatta zaman içinde bunun da ekolü oluşmuş; yukarıda bahsettiğimiz saray kökenli yazmalar bu ekollerden etkilenmiştir. Şarlman ve içinde bulunduğu entelektüel ve sosyal girişimler, zamanının siyasi ve kültürel ilerlemesinin nedeni miydi yoksa sonucu muydu? Cevap, 7. ve 8. yüzyıllarda başlayan hareketlerin onun zamanında doruğa ulaşmasıdır. Cermen istilalarının neden olduğu kafa karışıklığı ortadan kalkmış ve Germen ve Roma unsurları kaynaşarak yeni bir kültür üretmiştir. İrlandalı ve İngiliz misyoner ve öğretmenlerin çalışmaları etkisini göstermiş, eğitim, öğrenmeye ilgi artmış, dini coşku yayılmıştır. $\mathrm{Bu}$ misyonerlerin Roma'daki Kilise'ye olan sadakati, Kilise ve Devleti bir araya getirmiş; Papa tarafından Şarlman'ın taçlandırılmasını sağlamıştır (Ullman, 1980, s. 108). Özetle, Karolenj ekolü ve minüskülünün ortaya çıkışının tetikleyen etmenlerin Karolenj döneminden hemen önce belirlemeye başladığı, kendi karakteristik özelliklerini oturtmanın da Karolenj dönemi içinde gelişerek nispeten kısa zaman aldığg söylenebilir.

\section{Önde Gelen Karolenj Dönemi El Yazmaları \\ Godescalc İncili (Godescalc Evangelistary)}

Katalog bilgisi: Paris Ulusal Kütüphanesi (Paris, BNF. lat.1203)

Karolenj el yazması eser süsleme sanatı açısından ayrı bir sanatsal değer taşımaktadır. Önceki el yazmaları daha çok Merovenj etkisi taşırken Godescalc isimli rahibin yazdığı bilinen bu eser Ada ekolünün ilk örneklerinden kabul edilmektedir. Daha önce de bahsedildiği gibi 781-783 yılları arasında üretilen bu yazma, yazan rahibin adı ile anılmaktadır. Godescalc İncili, hem ön cepheden resmedilen ve tam bir sayfayı kapatacak şekilde resmedilmiş tahta oturmuş İsa görseli (Winckler, 1983, s.158) ile hem de Bizans ve birbirine geçmiş şekilde döşemeli arka plan sunumu ile Anglo-Saxon İrlanda esintileri sergiler. Erken dönem Hristiyan etkilerine de sahiptir. Kilise ayin ve törenlerinde okunacak metinler (lectionary) içeren bu eser, altın ve gümüş harf süslemelerine sahiptir. Eserin yazılmasının sebeplerinden biri Kralın hükümdarlığının 14. yılını ve ayrıca daha önceki bölümlerde bahsedilen Şarlman'ın oğlu Peppin'in Papa Hadrian tarafından vaftiz edilmesini onurlandırmaktır. 


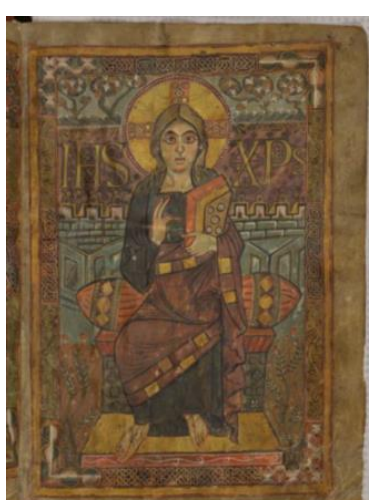

Görsel 1. Godescalc Kitabı'ndan İsa Görseli (Gallica, 2020c)

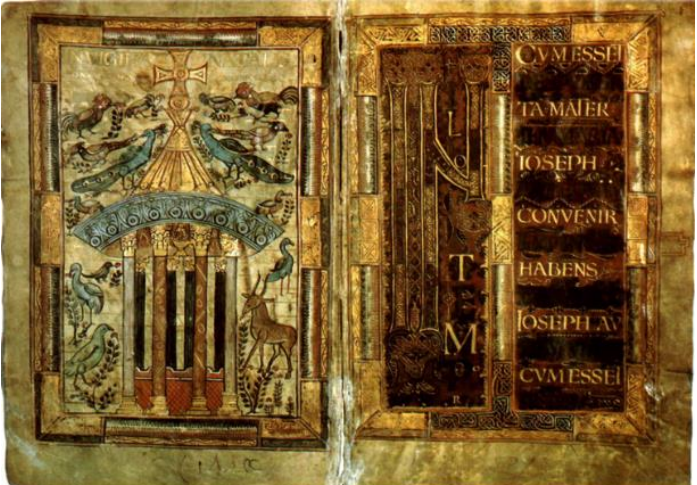

Görsel 2. Godescalc Kitabi'ndan hayat çeşmesi temsili (Gallica, 2020b)

\section{Aachen Kilise Kitabı (Aachen Gospels)}

Katalog bilgisi: Aachen Katedral Hazinesi (Inv.-Nr.4)

Saray ekolüne dahil edilen el yazmalarından biri de Aachen Kilise Kitabı'dır. 800'lü yılların başlarında daha önceki bölümlerde de bahsedilen Ada Ekolü'nü takip eden bir rahip tarafından yazıldığı düşünülmektedir. Çoğu zaman da Viyana Taç Giyme İncili olarak da anılmaktadır. Klasik illüzyonizm etkisi gösterir yani önceki eserlerde olduğu gibi düzlemleştirilmiş ve boyuttan yoksun görsellerden ibaret olmayan gölgelendirme teknikleri ile derinlik verilmiş görsellere sahiptir. Tek düze desenlendirilmiş zeminlerin yerine arka planda manzaralar ve görüntüler dikkat çekmektedir.

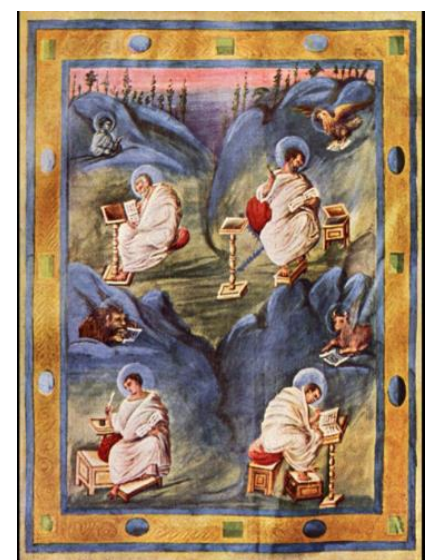

Görsel 3. Müjdecileri ile birlikte 'Dört Evanjelist Aziz' tasviri (Medievalwall, 2010)

\section{Montpellier Mezmuru (Montpellier Psalter)}

Katalog bilgisi: Montpellier Üniversitelerarası Tıp Kütüphanesi (Bibliothèque Interuniversitaire Médicine de Montpellier) (Ms. 409).

Şarlman saray okulu içindeki akademik tartışmalarda takma isim kullanıldığında İncil'den Davut karakterini canlandırmayı tercih ederdi. "Hristiyanlığın da etkisi ile Hz. Davut'un ilk imgelemleri saray sanatıyla yakın ilişki içinde yansıtılırdı. Bunlardan biri de Mondsee Manastırı'ndaki M.S. 783-792'de üretilen Montpellier Mezmuru tasvirlerinde gözlemlenebilir. Bu Mezmurun ön kapağı, müzisyen olarak Davut'un motiflerini ve Mesih'in imgelemlerini birleştirimektedir" (Garipzanov, 2008, s. 227). Günümüzde Avusturya'sının kuzeyinde Salzburg yakınlarındaki zamanın Bavyera Mondsee manastırında yazıldığı bilinmektedir. 


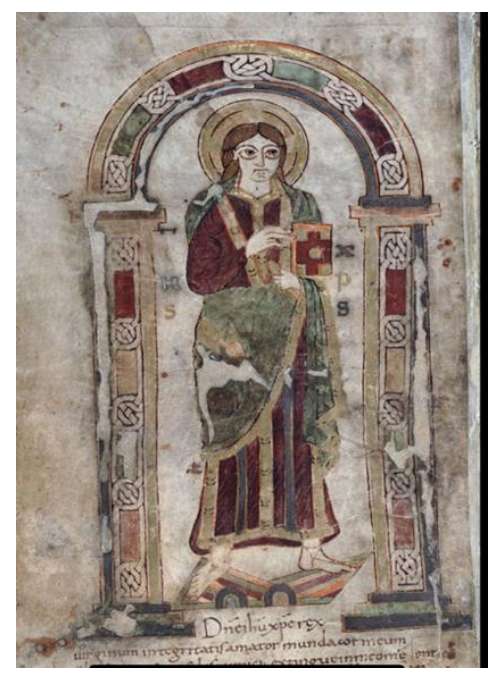

Görsel 4. Mezmurdan Ísa tasviri (Frankensaurus, 2020)

\section{Ada İncili (Ada Gospels)}

Katalog bilgisi: Trier Şehir Kütüphanesi (Stadtbibliothek) (Ms. 22)

8. yüzyılın sonları ile 9. yüzyılın başlarında üretildiği tahmin edilen Karolenj İncilidir. İsminden de anlaşılacağı gibi Şarlman'ın kız kardeşi olan Ada'ya adanmıştır ve yukarıda bahsedilen Ada Ekolünün en önde gelen örneklerindendir. Parşömen üzerine Karolenj minüskülü ile yazılmış olan eser Aziz Matthew, Mark ve Luke'un portre tasvirlerini içermekle birlikte Anglosakson (İrlanda), İtalyan ve Bizans esintileri taşımaktadır.

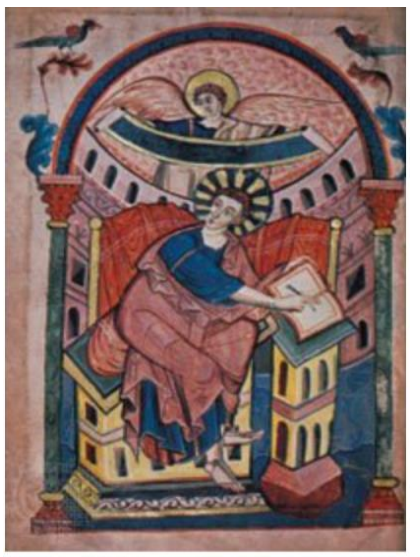

Resim 5. Evanjelist Mathew tasviri (Ada Group, 2020)

\section{Dagulf Mezmuru (Dagulf Psalter)}

Katalog bilgisi: Avusturya Ulusal Kütüphanesi, Viyana. (Österreichische Nationalbibliothek) (Cod. 1861).

Dagulf Mezmuru'un yaklaşık M.S. 783-795 yılları arasında saray ekolüyle üretildiği bilinmektedir. Kapağındaki fildişi kabartmaların Şarlman'ın sarayında üretildiği tahmin edilmektedir. Şarlman bu eseri Papa Hadrian'a verilmek üzere yaptırmıştır ancak Papa'nın 795 yılında ölmesi ile kendine iletilmemiştir. Fil dişinden kabartmalardaki tasvirler ve içinde Şarlman'ın onuruna ithafen yazılan şiir, mezmurların Davud'un altın sözleri olduğu ve Şarlman'ın da Davud'un varisi olduğu imasını taşımaktadır (Garipzanov, 2008, s. 227). 


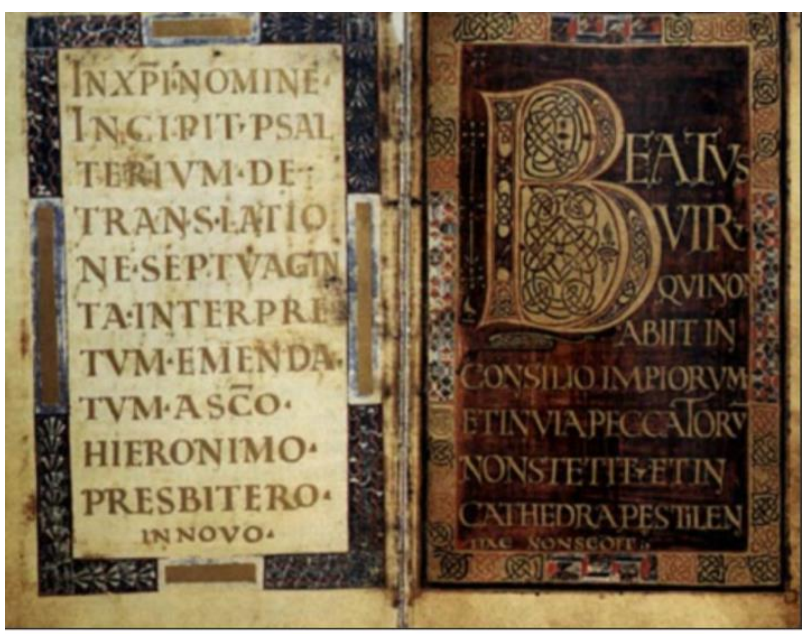

Görsel 6. Dagulf Mezmuru'ndan dekorlu yazı sayfası (Illuminated Manuscripts, 2008)

\section{Aziz Riquier İncili (St. Riquier Gospels)}

Katalog bilgisi: Belediye Kütüphanesi, Abbeville (Bibliothèque municipale) (Ms. 4).

Karolenj rönesansı döneminde üretilmiştir ve Ada Ekolü İncillerindendir. Bizzat Şarlman tarafından Aziz Riquier Manastırı baş rahibi Angilbert'e verildiği bilinmektedir: Altın ve gümüşle yazılan harflerin yanı sıra, dönem emsalleri mor parşömen üzerine hazırlanmıştır. "Zengin kanon tabloları, müjdecileri ile birlikte çizilen evanjelist yazman azizleri resmeden portreler ve ilk sayfaların programına ek olarak, İncil kitabı bir zamanlar değerli bir gümüş ciltle süslenmişti. El yazması muhtemelen Şarlman'dan, kitabın Orta Çağ boyunca korunduğu Amiens veya Arras'tan çok uzak olmayan Abbeville'de, Saint-Riquier'in başrahibi olan yakın danışmanı Angilbert'e bir hediye olarak M.S. 800 yılı civarında hazırlatılmıştır” (Kitzinger ve O’Driscoll, 2019, s. 235).

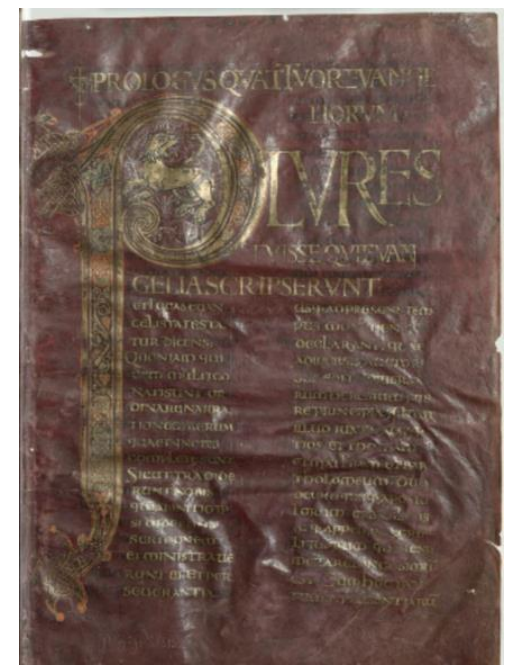

Görsel 7. Aziz Riquier İncili’nden dekorlu yazı sayfası (Gallica, 2020a)

\section{Vienna Taç Giyme İncili (Vienna Coronation Gospels)}

Katalog bilgisi: Viyana Hofburg Sarayl, Imparatorluk Hazinesi (Schatzkammer, Inv. XIII 18). M.S. 794- 800 yılları arasında Şarlman'ın saray okulunda üretildiği bilinmektedir. Frank Kral III. Otto tarafından 1000 yılında Şarlman'ın mezarı açıldığında gün yüzüne çıkmıştır yani Şarlman ölmeden üretilmiştir. Çoğu çağdaşı gibi evanjelist azizleri resmeden Bizans etkisinde kalmış görseller içermektedir. Kutsal Roma imparatorlarının taç giyme törenlerinde kullanıldığı 
tahmin edilmektedir. Kapağı 1500'lü yıllarda eklenmiş olmakla birlikte Viyana'daki Hofburg Sarayı'nda Schatzkammer olarak da adlandırılan imparatorluk hazinesi bünyesinde Inv. XIII 18 kodu ile muhafaza edilmektedir. Bu eserin en önemli özelliklerinden biri mora boyanmış bir parşömen üzerine yazılmış olmasıdır (purple codex). Mor renk eserin değerine atıfta bulunmak için kullanılmaktadır (Aceto ve diğerleri, 2017).

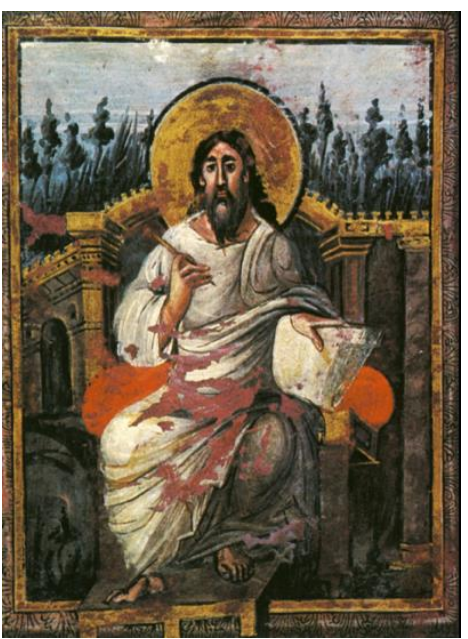

Görsel 8. Evanjelist Aziz John tasviri (Honour ve Fleming, 2005, s. 329)

\section{Codex Aureus of Lorsch}

Katalog bilgisi: Vatikan Apostolik Kütüphanesi (Biblioteca Apostolica Vaticana) (Pal. Lat. 50). El yazmasının kendisi kadar ön ve arka kapak olarak kullanılan panelleri de karakteristik özellikler göstermektedir. Eserin Aachen'da M.S. 810 yılları arasında yapıldığı düşünülen oyma kitap kapaklarından arka paneli Londra'daki Victoria ve Albert Müzesi'ndedir, 1555 yılında Heidelberg'de belgelendiği bilinen ön kapak, Heidelberg'deki Palatine Kütüphanesi'nin bir parçası olarak Otuz Yıl Savaşları zamanında buradan Roma'ya gönderilmiştir şimdi Vatikan Müzesi'nde saklanmaktadır. Ön parça muhtemelen daha önceki bir Geç Roma bağlamında kullanılmış ve hasar görmüş ve Karolenjler tarafından onarılmış ve bu amaçla takılmıştır. Kitabın ön kapağında, iki melekle çevrili, genç ve muzaffer bir Mesih'in Canavarlar üzerinde yürümesi görülmektedir; arka kapak, yanında Zacharias ve Vaftizci Yahya'nın yer aldı̆̆ı Bakire ve Çocuk'u tasvirleri bulunmaktadır. Ön alt panel, solda Hirodes'ten önce Frig kıyafeti giymiş Üç Kral'ı ve sağda üç Kralı, tahta çıkmış bir Bakire ve Çocuğun önünde, üzerlerinde Bethlehem Yıldızı ile gösterir. Mimari detay çerçeveler ve sahneleri pano üzerinde böler (Schutz, 2004, s. 283). 


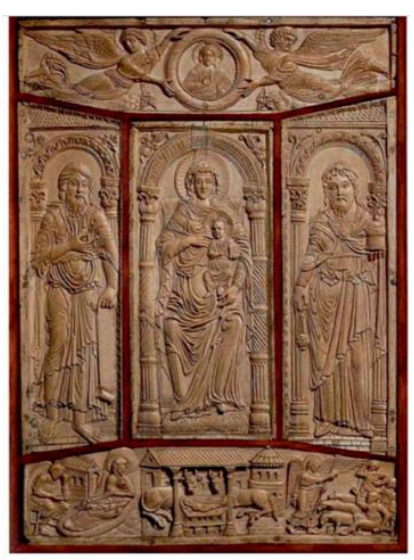

Görsel 9. Yeni Ahitten bir isim olan Zekeriya ile $\mathrm{Hz}$. Yahya'nın arasında tasvir edilmis Bakire Meryem ' $i$ kucă̆ında çocuk ile tasvir eden fil dişi kabartmalı arka kapak (Nathan ve Garland, 2011, s. 171).

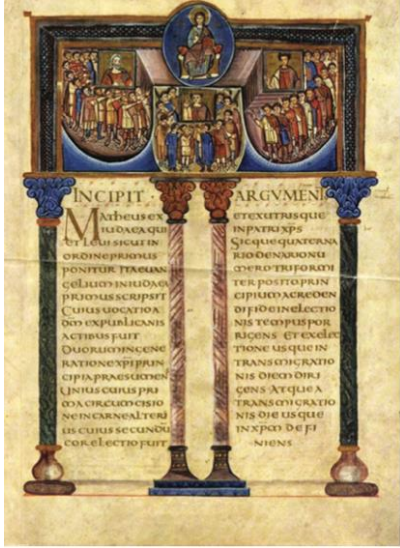

Görsel 10. Lorsch Incili’nden görsel ve yazı içeren bir sayfa (Răducu, 2018, s. 87)

\section{Saint-Médard de Soissons İncili (Saint-Médard de Soissons Gospels)}

Katalog bilgisi: Paris Ulusal Kütüphanesi (Ms. lat. 8850).

Saint-Médard de Soissons'ın İncilleri tartışmasız bir şekilde Şarlman'ın saray ekolünden gelmektedir. Mor olmayan parşömen üzerine, ancak mor renkte 800 civarında yapılmıştır. Başlık sayfaları, senaryo ve altın baş harfleri ve Dindar Louis tarafından éponyme manastırına teklif edilmiştir. Her ikisi de İncil kitaplarını tutan Aziz Mark ve onun sembolü aslanın bir tasvirini içerir. Bu resimdeki iki kitap mor sayfalardan oluşmakta ve İncilin ilk kelimelerini taşımaktadır. Bu iki kitap, Karolenj dönemi boyunca mor el yazmalarının son derece sembolik değerini tasdik ederek, izleyiciyi hemen içine çekecek kadar lüks ve ayrıntılarla temsil edilmiştir (Denoël ve diğerleri, 2018).

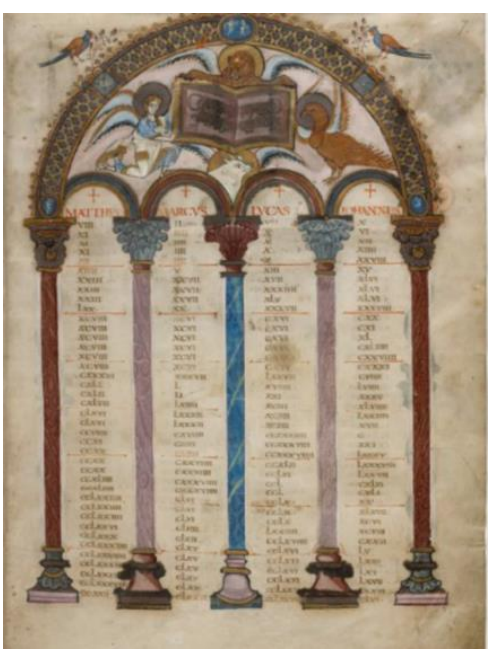

Görsel 11: Saint-Médard de Soisson İncili'nden süslemeli bir kanon tablosu (Gallica, 2020d)

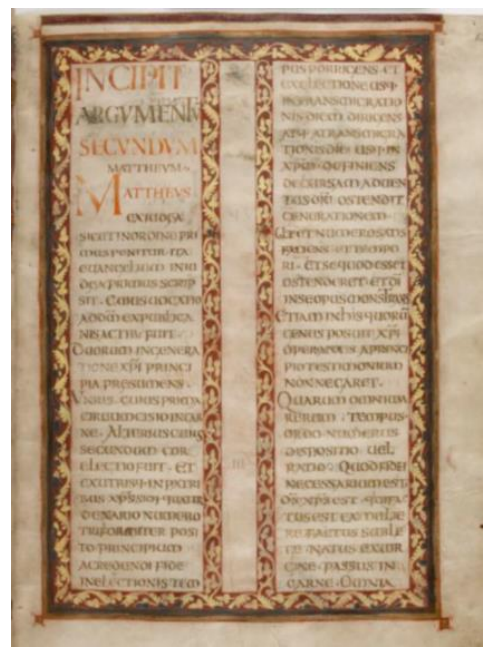

Görsel 12: Soisson Incili’nden bir metin örneği (Gallica, 2020e)

\section{Ebbo Gospels (Ebbo İncili)}

Katalog bilgisi: Épernay Belediye Kütüphanesi (Bibliothèque Municipale) (Ms. 1). Saray okulunun temeli Şarlman'ın ölümünden sonra sarsılmaya ve yok olmaya yüz tutmuş olsa da, Taç Giyme İncilleri'nin ve benzer klasik canlandırılmış eserlerin etkisi 814'lü yıllardan sonra 
önem kazanmaya başlamıştır. Utrecht Mezmuru gibi Reims'li Başrahip Ebbo'nun ismi ile anılan (M.S. 810-845 yılları arasında başrahiplik yapmıştır) İncili de Vienna İncili etkisinde üretilmiştir (Gowing, 2002, s. 541). Bu yeni ekolde görsel sanatçıları mimikleri ve pozları daha detaylı resmeden bir şekilde eski Klasik el yazması tasvirlerine tercih etmiş, duyguların yansıtılmasına önem vermişlerdir ki bu onların Batı Avrupa sanatının geleceği için yaptıkları en büyük katkıdır (Honour ve Fleming, 2002, s. 344).

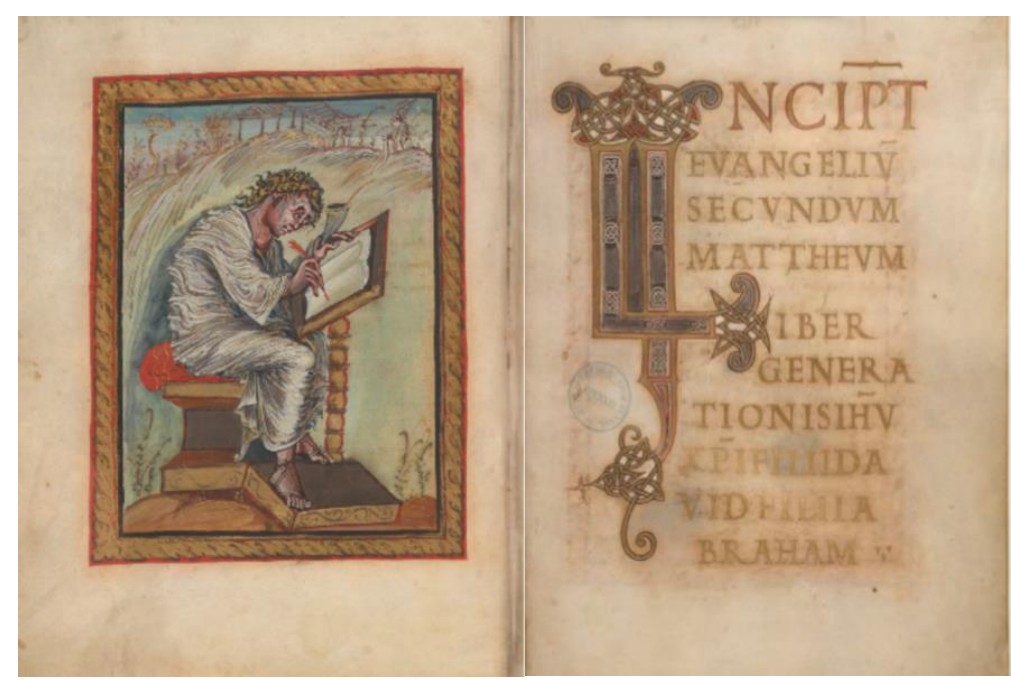

Görsel 13. Yazman Aziz. Mathew tasviri ve dekorlu yazı sayfası (Gallica, 2020f)

\section{Utrecht Mezmuru (Utrecht Psalter)}

Katalog bilgisi: Utrecht Üniversite Kütüphanesi (MS Bibl. Rhenotraiectinae I Nr 32).

$\mathrm{Bu}$ mezmur, yaklaşık olarak M.S. 816-823/835 yılları arasında Reims şehri eteklerindeki Hautvillers'daki Aziz Peter manastırında yazıldığı tahmin edilen dönemine göre oldukça yenilikçi bir çalışmadır. Kraliçe Judith (Şarlman'ın oğlu Dindar Louis'nin eşi) için yazılmış olabileceği de bildirilmektedir. Godescalc isimli yazmaların sahibi rahibin de yazımında yer aldığı düşünülmektedir (Schutz, 2004, s. 269)

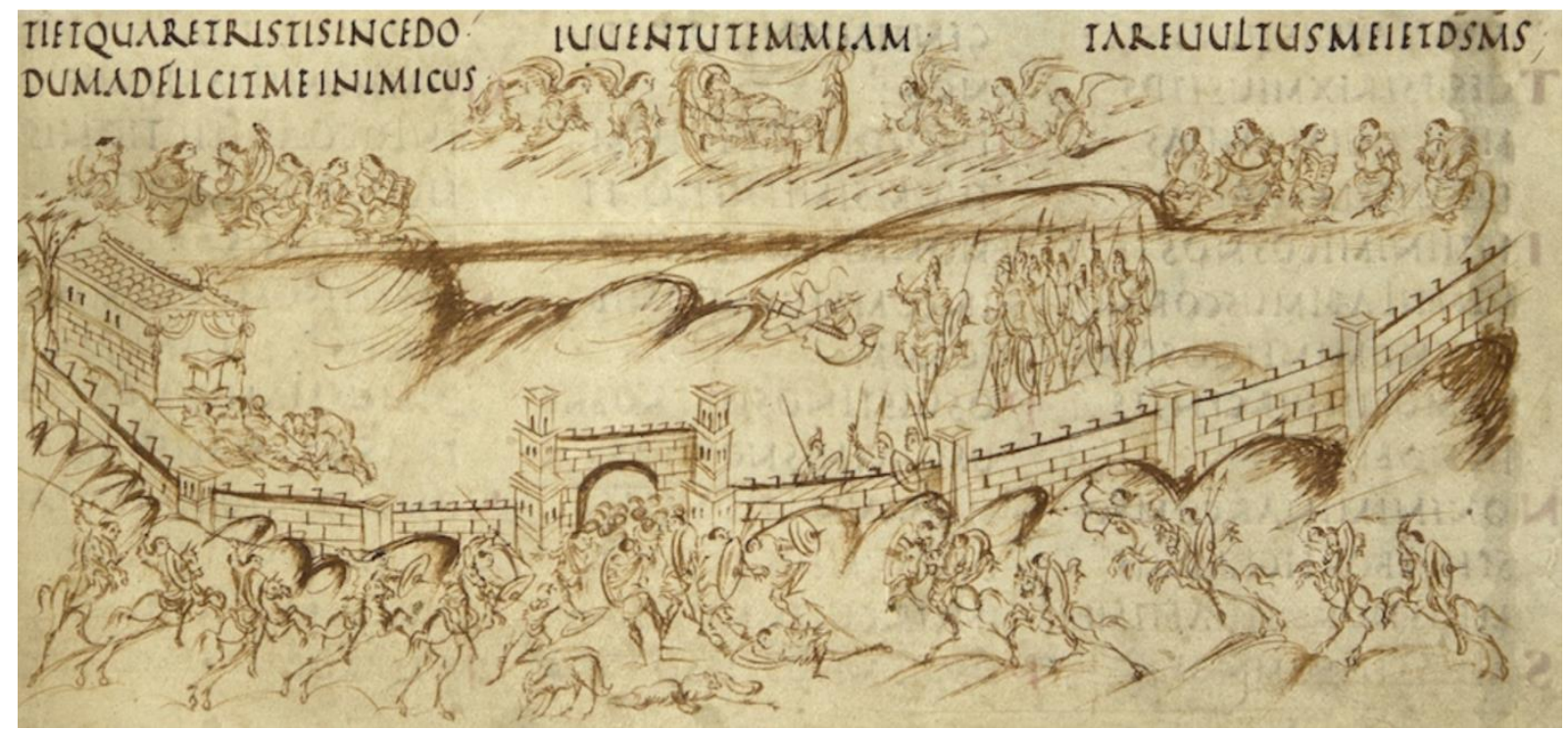

Görsel 14. Utrecht Mezmuru'ndan bir kuşatma temsili (Khan Academy, 2020) 


\section{Sonuç}

Devlet yönetimine sosyal ve siyasi anlamda bir standart getirmeyi hedefleyen Şarlman'ın ilk hedeflerinden biri derin bir ahlaki ve idari çöküş içinde olduğunu düşündüğü ruhban sınıfının eğitimini düzenlemek olmuştur. Bu yenileşme manastırların yazıhanelerinde köklü bir değişimle ortaya çıkmıştır. Manastırlar bu dönemde ruhban sınıfının eğitim aldığı kurumlar oldukları yani birer dini eğitim merkezi oldukları kadar Klasik dönem Antik Yunan ve Roma eserlerinin Karolenj minüskülü ile çoğaltıldığı yazıhanelere ev sahipliği yapan kurumlar da olmuşlardır.

Ancak manastırlarda muhafaza edilen Kilise bilgeliğinin sessizce varlığını idame edip bilgiyi koruduğu yüzyıllar Orta Çağın karanlığı veya "karanlık devirler" olarak itham edilse de bu dönemden önce Karolenj reformundan kalan çoğu şey, çok geçmeden silinmeye başlamıştır yani bu rönesans uzun soluklu olamamıştır. Bunun ilk öncüllerinden biri, Şarlman'ın ölümü ve topraklarının muhafaza edilememesi sonucu bölünerek torunları tarafından idare edilmeye başlaması olmuştur. Frank topraklarında 9. yüzyıl genelinde ve sonrasında bir süre Avrupa genelinde olduğu gibi okur-yazarlık, eser üretimi, kütüphane kodekslerinde kayıtlı eser sayılarında yani entelektüel alanda genel bir düşüş yaşanmıştır. Şunu da belirtmek gerekir ki bu yenilenme hareketi yalnızca belirli alanlar üzerinde yoğunlaşmıştır ve belli kesimin kültürel ve entelektüel seviyesini yükseltme amaçlı gerçekleştirilmiştir. Ancak bunun yanı sıra manastır yan/iç okulları açılması gibi geneli etkileyen tarzda iyileştirme girişimleri de Şarlman döneminde çıkarılan fermanlarla görülebilecek bir gelişme olarak değerlendirilebilir.

Tarihi olgusu açısından Karolenj dönemi Şarlman'ın askeri-siyasi tutku ve hedeflerinin çoğunu gerçekleştirerek Kutsal Roma Germen İmparatorluğu'nu kurduğu ve Kutsal Roma İmparatoru unvanını alışı ile topraklarının bugün üç ülke sınırını da içine alacak şekilde genişlediği dönemdir. Bu durum, yani ekonomik refah ve siyasi ilişkilerin iyi oluşu entelektüel girişimler için de elverişli ortamı sağlama açısından gerekli unsurlardır.

Eğitim ve bilgi tarihi açısından; İtalyan Rönesans'1 öncesi sınırlı bir rönesans olarak manastır ve saray yazıhanelerinde Antik Yunan ve Roma klasik dönem eserlerinin çoğaltılarak İtalyan Rönesansı'na değin korunabilmesi, Alcuin'in modern çağ üniversitelerinin temelini atacak bilimler olan 'liberal sanatlar' veya bugünkü adıyla sosyal bilimleri manastır, katedral ve saray okulu gibi ortamlar ile süreçlere dahil etmesi oldukça elzem gelişmelerdir.

Karolenj yazı stili olan minüskülün oluşturulması ile Latince metinlerin okunmasına ve yazıhanelerde yazman keşişler tarafından nüshaları çoğaltılan el yazmaları eserler üzerine bir tekel oluşturmaya çalışılması; bu dönemde saray ve manastır kütüphaneciliğinin de gelişmesi anlamına gelmektedir.

Dönem içinde tasvir ve süsleme tarzlarında değişiklikler gözlemlenebilir olsa da altın ve kıymetli taş ve mücevherat ile süslenen el yazmalarının kendi içinde belirli ekoller oluşturarak çeşitlenmesi noktasında bu dönem kendinden önce ve hemen sonra gelen imparatorluklar ve entelektüel yaklaşım itibariyle farklılaşmıştır. Ancak bu el yazmaları akımı yalnızca Şarlman yönetimi zamanı ile sınırlı kalmamış torunu Dazlak Karl'ın sarayının ekollerinin ortaya çıktığı zamana kadar devam etmiştir. Karolenj dönemine kadar el yazmalarının temel konu alanlarının neredeyse tamamen İncil ve Kilise metinleri, azizlerin ve kilise babalarının hayatlarına yönelik bilgiler, mezmurlar ve metinleştirilmiş manastır tarikat kuralları gibi dini temelli olduğu ancak 
bu dönemle birlikte Klasik Dönem eserlerindeki bazı seküler temaların da manastırların kitap çoğaltırken tercihleri arasında yer almaya başladığı görülmektedir.

Diğer taraftan, bu çalışmanın özellikle Orta Çă̆ Avrupası ve yakın coğrafyalarda üretilen al yazmalarının müteakip dönemlerde sergiledikleri nitelikler, çoğaltılmalarına yönelik yaklaşımlar ve gerek manastır gerekse saray kütüphanelerinde muhafaza edilmeleri kadar güncel durumları bağlamında da gelecek çalışmalara 1şık tutacağı değerlendirilmektedir.

\section{Kaynakça}

Aceto, M., Agostino, A., Fenoglio, G., Idone, A., Crivello, F., Griesser, M., ... ve Puyo, P. R. (2017). Analytical investigations on the Coronation Gospels manuscript. Spectrochimica Acta Part A: Molecular and Biomolecular Spectroscopy, 171, 213-221.

Ada Grouo: Carolingian art. (2020). Evanjelist Mathew tasviri. https://www.britannica.com/art/Adagroup

Avrin, L. (2010). Scribes, script, and books: the book arts from antiquity to the renaissance. Chicago: American Library Association.

Aydın, M. (2005). Ansiklopedik dinler sözlü̆ğü. NKM, Nüve Kültür Merkezi.

Butt, J. (2002). Daily life in the age of Charlemagne. Greenwood Publishing Group.

Cairns, E. E. (2009). Christianity through the centuries: A history of the Christian Church. Michigan: Zondervan Academic.

Claster, J. N. (1982). The Medieval experience, 300-1400. NYU Press.

Denoël, C., Puyo, P. R., Brunet, A. M., ve Siloe, N. P. (2018). Illuminating the Carolingian era: New discoveries as a result of scientific analyses. Heritage Science, 6(1), 1-19.

Dodwell, C. R. (1993). Ottonian book illumination: An Historical Study. The English Historical Review, 108(426), 135-138.

Eginhard. (1880). Life of Charlemagne. American Book Company.

Erkoç, S. (2014). Comparing higher education in Roman Empire \& in its Islamic Arabian and Asian counterparts in early middle ages (Erken Orta Çăg'da Roma Imparatorluğu ile Arap ve Asya emsallerinde yükseköğretimin karşılaştırılması [Yayımlanmamış yüksek lisans tezi]. Sakarya Üniversitesi.

Fichtenau, H. (1978). The Carolingian empire. (C. 1). University of Toronto Press.

Frankensaurus: The enormous Thesaurus Freak. (2020). Mezmurdan Isa tasviri. https://frankensaurus.com/Montpellier_Psalter

Frassetto, M. (2013). Encyclopedia of Barbarian Europe: Society in transformation. ABC-CLİO.

Gallica. (2020a). Aziz Riquier Incili'nden dekorlu yazı sayfası = Manuscrits de la bibliothèque d'Abbeville. https://gallica.bnf.fr/ark:/12148/btv1b55005654j/f5.item

Gallica. (2020b). Godescalc Kitabı'ndan hayat çeşmesi temsili = Evangeliarium [Evangéliaire dit de Charlemagne ou de Godescalc]. https://gallica.bnf.fr/ark:/12148/btv1b6000718s/f5.item.r=godescalc

Gallica. (2020c). Godescalc Kitabi'ndan Ísa görseli = Evangeliarium [Evangéliaire dit de Charlemagne ou de Godescalc]. https://gallica.bnf.fr/ark:/12148/btv1b6000718s/f5.item.r=godescalc

Gallica. (2020d). Saint-Médard de Soisson Incili'nden süslemeli bir kanon tablosu = Evangelia quattuor [Évangiles de Saint-Médard de Soissons] (1v-221v). Capitulare evangeliorum (223r-235v). https://gallica.bnf.fr/ark:/12148/btv1b8452550p/f35.item.zoom 
Gallica. (2020e). Soisson İncili'nden bir metin örneği = Evangelia quattuor [Évangiles de Saint-Médard de Soissons] (1v-221v). Capitulare evangeliorum (223r-235v). https://gallica.bnf.fr/ark:/12148/btv1b8452550p/f35.item.zoom

Gallica. (2020f). Yazman Aziz Mathew tasviri ve dekorlu yazı = Manuscrits de la bibliothèque d'Epernay. Évangéliaire dit d'Ébon. https://gallica.bnf.fr/ark:/12148/btv1b8458375p/f44.item.zoom

Garipzanov, I. (2008). The symbolic language of authority in the Carolingian world (C. 751-877). Brill.

Genç, Ö. (2013). Birleşik Avrupa'nın mimarı Şarlman ve Karolenj Rönesansı. Lotus Yayınevi.

Gowing, L. (2002). A history of art. Borders Press.

Halfond, G. (2010). The archaeology of Frankish church councils, AD 511-768. Brill.

Hen, Y. (1995). Culture and religion in Merovingian Gaul: AD 481-751. (C. 1). Brill.

Hildebrandt, M. (1992). The external school in Carolingian society. (C. 1). Brill.

Hodgkin, T. (1902). The life of Charlemagne. A. L. Burt.

Honour, H., ve Fleming, J. A (2002). World history of art. Laurence King.

Illuminated manuscripts. (2008). Dagulf Mezmuru'ndan dekorlu yazı sayfası. https://illuminatedmanuscripts.wordpress.com/2008/10/29/dagulf-psalter/

Khan Academy. (2020). Utrecht Mezmuru'ndan bir kuşatma temsili = Matthew in the Coronation Gospels and Ebbo Gospels. https://www.khanacademy.org/humanities/medievalworld/carolingian-ottonian/carolingian1/a/matthew-coronation-and-ebbo-

Kitzinger, B., ve O’Driscoll, J. (Yay. Hazl.). (2019). After the Carolingians: Re-defining manuscript illumination in the 10th and 11th Centuries. Walter de Gruyter.

Loveluck, C. (2013). Northwest Europe in the early middle ages, c. AD 600-1150: A comparative archaeology. Cambridge: Cambridge University Press.

Lynch, J. M., ve Lynch, J. H. (1998). Christianizing kinship: Ritual sponsorship in Anglo-Saxon England. Ithaca, London: Cornell University Press.

McKitterick, R. (1989). The Carolingians and the written word. Cambridge: Cambridge University Press.

McKitterick, R. (2004). History and memory in the Carolingian world. Cambridge: Cambridge University Press.

Nathan, G., ve Garland, L. (Yay. Hazl.). (2011). Basileia: Essays on imperium and culture in honour of EM and MJ Jeffreys. Brill.

Osborne, J. (1990). The use of painted initials by Greek and Latin scriptoria in Carolingian Rome. Gesta, 29(1), 76-85.

Painter, W. E. (1850). The seventh general council, the second of Nicaea, Held AD 787, in which the worship of Images was established: with copious notes from the "Caroline Books", compiled by order of Charlemagne for Its confutation. William Edward Painter.

Răducu, M. (2018). Salonul Naţional de Artă Medievală. 18 septembrie-19 octombrie 2017. Expoziţia de artă plastică şi decorativă Ipostaze Medievale-Interferenţe C@ rte ProPatrimoniuRevalorificări contemporane. Biblioteca Naţională a României. Biblioteca, 2018(3), 87-96.

Riché, P. (1993). The Carolingians: A family who forged Europe. Philadelphia: University of Pennsylvania Press.

Rowling, M. (1973). Life in medieval times. Perigee Book.

Schutz, H. (2004). The Carolingians in Central Europe, their history, arts, and architecture: A cultural history of Central Europe, 750-900 (C. 18). Brill. 
Karolenj Rönesansı Bağlamında Kütüphaneler, Manastırlar ve Karolenj El Yazmaları

Ullman, B. L. (1980). Ancient writing and its influence. (C. 10). University of Toronto Press.

Winckler, P. A. (1983). Reader in the history of books and printing (C. 26). Greenwood Publishing Group. 